\title{
Okul Öncesi Dönemde Kültürel Miras Eğitimine Illişkin Öğretmen Görüşleri: Denizli ili Örneği
}

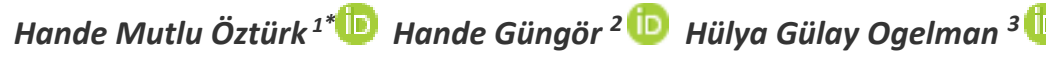 \\ 1 Pamukkale Üniversitesi, Turizm Fakültesi, hmozturk@pau.edu.tr, ORCID: 0000-0002-4404-0106 \\ 2 Pamukkale Üniversitesi, Sağlık Hizmetleri MYO, hgungor@pau.edu.tr, ORCID: 0000-0002-3016-1775 \\ 3 Sinop Üniversitesi, Eğitim Fakültesi, ogelman@sinop.edu.tr, ORCID: 0000-0002-4245-0208 \\ Öz
}

Kültürel miras geçmişten günümüze gelen ve gelecek nesillere aktarılması gereken değerler bütünüdür. Bu çalışmada okul öncesi öğretmenlerin kültürel miras algısı ve okul öncesinde kültürel miras eğitime bakış açıları araştırılmıştır. Çalışma Denizli'de okul öncesi çocuklarla çalışan 74 öğretmeninin kültürel miras eğitimine ilişkin görüşlerinin belirlenmesini amaçlamaktadır ve çalışmada nitel araştırma yöntemlerinden tekli durum çalışması ve örnekleme yöntemlerinden amaçlı örnekleme yöntemi kullanılmıştır. Çalışmada veri toplama aracı olarak araştırmacılar tarafından geliştirilen yapılandırılmış görüşme formu kullanılmıştır ve elde edilen verilerin analizinde betimsel analiz tekniğinden yararlanılmıştır. Çalışmada, öğretmenlerin yaklaşık yarısının kültürel miras denildiğinde "bir milletin geçmişten günümüze gelen maddi ve manevi değerleri" düşündükleri ortaya konulmuştur. Bunun yanı sıra gelenek, "gelenek, görenek, örf ve adetler", "milli değerler" ve "evrensel değerler" gibi farklı cevaplar da verilmiştir. Öğretmenler kültürel mirası çoğunlukla bir milletin geçmişten günümüze gelen maddi-manevi değerleri olarak görmektedir ( $n=50$; \%48.54). Okul Öncesi öğretmenler kültürel miras öğeleri arasında doğal ve tarihi alanları ( $n=59 ; \% 38.31$ ) ilk sırada görmektedirler. Ankete katılanların tamamı okul öncesi dönemde kültürel miras eğitimi verilmesi yönünde görüş belirtmiştir. Öğretmenlerinin okul öncesi dönemde kültürel miras eğitimine yer verilmesine yönelik nedenleri arasında en çok "ağaç yaş iken eğilir" ( $n=21$; \%24.14) ve "kültürü öğrenmek ve korumak için" ( $n=18$; \%20.69) nedenleri gelmektedir. Ankete katılan öğretmenlerin tümünün çocuklar ile kültürel miras eğitimine yönelik olarak, kültürel miras eğitiminde sanat etkinliği, fen etkinliği, matematik etkinliği, Türkçe etkinliği, oyun etkinliği, okuma yazma hazırlık etkinliği, alan gezisi ve drama etkinlikleri yaptırdıkları anlaşılmaktadır. Katılımcıların yarısından fazlasının ( $n=40 ; \% 54.05)$ eğitim programının kültürel miras eğitiminde beklentilerini karşıladığı görülürken, 34 katıımcının (\%44.05) konu ile ilgili beklentilerini karşılamadığı anlaşılmaktadır. Öğretmenlerin büyük bir çoğunluğunun ( $n=68 ; \% 91.89)$ kültürel miras eğitiminde materyal kullandığı ve konu ile ilgili hizmet içi eğitim almadıkları ( $n=62 ; \% 83.78)$ görülmüştür.

Anahtar Kelimeler: Kültür, Kültürel Miras Eğitimi, Okul Öncesi Dönem, Öğretmenler

\section{Teachers' Views on Cultural Heritage Education in Preschool: The Case of Denizli}

\section{Abstract}

Cultural heritage is a set of values that have come from the past and should be passed on to future generations. In this study, preschool teachers' perception of cultural heritage and their perspective on cultural heritage education in preschool were investigated. The study aims to determine the views of 74 teachers on cultural heritage education who work with preschool children in Denizli. In the study, purposeful sampling method, among qualitative research methods, single case study and sampling methods were used. In the study, the structured interview form developed by the researchers was used as the data collection tool, and the descriptive analysis technique was used in the analysis of the data obtained. In the study, it was revealed that nearly half of the teachers think of "the material and moral values of a nation from the past to the present" when cultural heritage is mentioned. In addition, different answers were given such as "tradition", "customs and traditions", "national values" and "universal values". Teachers mostly consider cultural heritage as the material-spiritual values of a nation from the past to the present ( $n=50 ; 48.54 \%)$. Preschool teachers consider natural and historical areas ( $n$ $=59 ; 38.31 \%)$ in the first place among cultural heritage items. All of the respondents expressed their views on cultural heritage education in the preschool period. Among the reasons for teachers to include cultural heritage education in the preschool period, the most common reasons are "the tree bends at its age" $(n=21 ; 24.14 \%)$ and "to learn and protect culture" ( $n=18 ; 20.69 \%)$. It is understood that all of the teachers participating in the questionnaire have organized art activities, science activities, mathematics activities, Turkish activities, games activities, literacy preparation activities, field trips and drama activities in cultural heritage education with children. While it is observed that more than half of the participants ( $n=40 ; 54.05 \%)$ met their expectations in cultural heritage education, it is understood that 34 participants (44.05\%) did not meet their expectations on the subject. It was observed that the majority of the teachers $(n=68 ; 91.89 \%)$ used materials in cultural heritage education and did not receive in-service training ( $n=62 ; 83.78 \%$ ).

Keywords: Culture, Cultural Heritage Education, Preschool Period, Teachers
Araştırma Makalesi

Cilt 5, Sayı 1, 2021

ss. $175-203$

Gönderim : 10.02.2021

1. Düzeltme: 10.03 .2021

Kabul Tarihi: 26.03.2021

Research Article

Vol 5, No 1, 2021

pp. $175-203$

Received : 10.02.2021

Revision1: 10.03 .2021

Accepted: 26.03.2021

\section{Önerilen Atıf/Suggested Citation}

Öztürk, H.M., Güngör, H. ve Ogelman, H.G. (2021). Okul Öncesi Dönemde Kültürel Miras Eğitimine Illişkin Öğretmen Görüşleri: Denizli ili Örneği. Güncel Turizm Araştırmaları Dergisi, 5(1), 175-203.

*Sorumlu yazar e-posta: hmozturk@pau.edu.tr 


\section{GİRIŞ}

Miras geçmişten günümüze kalan ve gelecek nesillere aktarılacak değerlerle ilgilidir. Kültürel ve doğal miras, atalarımızdan bizlere aktarılan mirastır ve gelecek nesillere aktarılması gereken değerler bütünüdür. Kültürel miras, geçmişten günümüze aktarılan büyük bir tecrübe ve birikimdir; gelenekleri, inançları, değerleri ve başarıları içerir. Kültürel miras hem somut hem de soyuttur. Somut veya maddi miras, antlar, binalar, resimler ve nesneler gibi fiziksel olarak dokunulabilen şeyleri ifade eder. Öte yandan somut olmayan miras, kuşaktan kuşağa aktarılan ve toplumların geçmişten günümüze taşıdıkları müzik, dans, edebiyat, dini törenler, efsaneler, destanlar, hikâyeler vb. gibi kültürel değerleri ifade eder.

Kültürel miras çocukların geçmişi anlamasını sağlar ve geleceğe 1şık tutar. Kültürel miras öğeleri yüzyılların günümüze ulaşan birikimlerdir. Yaşanan dönem geçmiş ile geleceğin kesişim alanı gibi düşünülebilir. Geçmişi görmek ve hissetmek, çocuğun içindeki sanatsal duyguları besler ve dışarı çıkmasını sağlar. Kültürel mirasın öğelerinden ancak korunanlar bugüne ulaşmıştır. Tarihin görülebilir kısmıdır. Kaybolan ve bugüne ulaşamayanlar insanlığın kaybolan zenginliklerdir.

İnsanlığın bugün sahip olduğu her başarıda geçmiş kuşakların birikimleri vardır. $\mathrm{Bu}$ birikimleri anlamak çocukta yaratıcıllğı besler. Yaratıcı ve sanatsal çalışmaları desteklemek için çocukların bu mirasın bir parçası olarak hissetmelerini sağlamak gerekir. Her roman, geçmiş mitler, destanlar, efsaneler, atasözleri, fıkralar vb. izler taşır. Her mimari eserde geçmiş dönem mimarlarının bir katkısı vardır. Her mühendislik yapısında da geçmiş dönemlerin bilgi ve deneyimlerinin payı vardır. $\mathrm{Bu}$ nedenle geçmişi ve kültürel miras değerleri anlamaya çocukları teşvik etmek gerekir.

Eğitimde kültürel miras öğretisinin etkisi konusunda birçok çalışma yapılııştır, ancak okul öncesi eğitimde kültürel miras konusu ile ilgili çalışmalar sınırlıdır. Kültürel mirasın okul öncesinden başlayarak çocuklarda bu konuda farkındalık yaratmak; değerlerini ve kültürel mirası tanıması ve koruması için oldukça önemlidir. Kültürel miras eğitiminde üzerinde durulması gereken en önemli noktalardan birisi de eğiticilerin bu konuya bakış açları ve kültürel miras eğitimi ile ilgili düşünceleridir. $\mathrm{Bu}$ çalışmada okul öncesi eğitimde eğiticilerin kültürel miras konusundaki yaklaşımları ele alınmıştır. Ülkemizde bu kapsamdaki çok sınırlı çalışma olması ve bu çalışmanın yürütüldüğü Denizli' de ise bu konuda herhangi bir çalışmanın yapılmamış olması çalışmanın özgün yanları arasında yer almaktadır. Kültürel miras kavramının evrensel boyutlarının yanı sıra yerel farklılıklar ve yaklaşımlar da içermesi nedeni ile bu çalışma birçok yenilik ve özgünlük içermektedir.

\section{LİTERATÜR TARAMASI}

Doğal miras, doğal güzelliği gösteren peyzajlarla veya nesli tükenmekte olan hayvan veya bitki türlerini içeren habitatlarla ilgilidir (Aslan ve Ardemagni, 2006; Barghi, Zakaria, Hamzah ve Hashim, 2017). Kültürel miras, bize geçmişte insan gruplarının nasıl yaşadığını, değerlerini ve çeşitli grupların birbirleriyle nasıl ilişkili olduğunu ve nasıl etkileşime girdiğini anlatan eşsiz ve yeri doldurulamaz bir kaynaktır (Dönmez 
ve Yeşilbursa, 2014; Köroğlu, Ulusoy ve Avcıkurt, 2018; Eryazıcıŏlu ve Cengiz, 2018). $\mathrm{Bu}$ nedenle kültürel miras, hayatımızdan anlam çıkarma sürecinin temel bir parçasıdır, sosyal kimliğimizin temel bir bileşenidir ve insanlar arasında barış ve anlayışı tesis etmek için bir yoldur (Asunakutlu ve Safran, 2004; Keskin ve Keskin, 2009; Özünel Ölçer, 2017). Eşsiz ve yeri doldurulamaz bir kaynak olmasına rağmen, kültürel miras yine de bir dizi doğal ve insan yapımı tehdide (örneğin depremler, sel, yangın, yağma, askerî harekât ve modern kalkınma) karşı korumasızdır ve hassastır. Kültürel mirasın bu kadar duyarlı olması, onu koruma ve kollama çabalarının öneminin altını çizmektedir (Aslan ve Ardemagni, 2006; Schindler ve Bonebright, 2011; Barghi vd. 2017; Öztürk ve Öztürk, 2019). Bununla birlikte, sürdürülebilir koruma, eğitim yoluyla aşılanabilir, halkta farkındalık yaratılabilir ve mirasa karşı bir koruma duygusu ve sahiplenme yaratılabilir (Curtis ve Seymour, 2004; Copeland, 2006; Hunter, 1988, 1992). Bugünün çocuklarına, ilkokuldan yükseköğretime kadar eğitim yoluyla, mirası koruma ve kollama sorumluluğu verilerek miras konusunda toplum bilinci artırılabilir (Schindler ve Bonebright, 2011; Yesilbursa ve Uslu, 2014). Eğitim yoluyla mirasın korunması son zamanlarda yaygın bir ilgi görmüştür. Eğitim, sürdürülebilir mirasın korunmasını kurumsallaştırmak ve mirası daha geniş bir kitleye iletmek için resmi bir mekanizma sağlar (Hunter, 1988; Patrick, 1988; Copeland, 2006). Kültürel miras eğitimi, kültürel materyalleri, kültürel miras aracılığıyla tarihi ve yaşanan kültürü anlamayı teşvik etmeyi amaçlayan bir öğretme ve öğrenme yaklaşımıdır ve paylaşılan bir kültür duygusunu öğretmek veya güçlendirmek için eğitim alanını kullanan bir dizi metodolojiyi içerir. Bu nedenle kültürel miras eğitimi, insanların kültürel miraslarını kaplayan değerler, temalar ve olaylara ilişkin farkındalığını ve takdirini artırır (Hunter, 1992). Kültürel miras eğitiminin önemini vurgulayan uygulamalarla günümüz çocukları, kolektif mirasımızın korunmasından ve bu mirasın gelecek nesillere aktarılmasından sorumludur. Bu nedenle kültürel miras eğitimi, öğrencileri bu alandaki bilgilerini artırarak değerlerini koruma sürecine daha aktif bir şekilde dâhil olmaya, miras alanlarına ve geleneklerine değer vermeye teşvik eder. Aynı zamanda, kültürel miras eğitiminin amacı, sadece çocukların tarihi yerler ve nesneler hakkındaki bilgilerini artırmak değil, aynı zamanda bu tarihi nesneler ve gelenekler üzerinde bir sahiplik duygusu aşılamak ve böylece onları bu mirasın korunmasından aktif olarak sorumlu kılmaktır (Copeland, 2004). Kültürel miras eğitimi, öğrencilerin nereden geldiklerini anlamalarına yardımcı olur ve gelecekte nereye gidebilecekleri konusunda bir rehber görevi görür. Bununla birlikte, kültürel miras eğitiminin kendi başına ayrı bir müfredat konusu olmadığına dikkat etmek önemlidir (Hunter, 1992). Copeland'a (2006) göre kültürel miras eğitimi, ders planlamasını artırmak için mirastan yararlanabilen tarih, coğrafya, diller ve geometri gibi çeşitli konuların öğretimine yönelik müfredatlar arası bir yaklaşımdır. Copeland (1991) kültürel miras eğitimini şu şekilde sınıflandırmıştır: (a) Kültürel miras hakkında bilgi geliştiren miras hakkında eğitim ve (b) Kültürel mirasın matematik (Copeland, 1991), fen (Pownall ve Hutson, 1992), coğrafya (Copeland, 1993) sanat (Lockey ve Walmsley, 1999) ve diller (Collins ve Hollinshead, 2000) gibi çeşitli konuların 
öğretilmesi sürecinde müfredatlar arası bir araç olarak kullanıldığı kültürel miras yoluyla eğitim yaklaşımı.

Teknoloji ilerledikçe ve popüler kültür yaygınlaştıkça, çocukların kendi kültürlerini öğrenmesi ve yaşaması zorlaşabilmektedir. Çocukların kültürel tavırlar ve kimliklerle çok erken yaşta tanıştıkları düşünüldügüünde, ilk yıllardan itibaren köklü bir sorumluluk ve koruma kültürü geliştirmek, çocukların doğal olarak çevrelerine bağlı hissetmelerini sağlamak giderek daha kritik hale gelmektedir (Haddad, 2014). Erken çocukluk, büyük ölçüde gelecekteki zihinsel ve duygusal iyilik düzeyini belirler (Kourmousi, 2012). Temel tutum ve davranışlar erken çocukluk döneminde pekişir (Bourotzoglou, 2018). Lynch ve Hanson (1998) bize "kişinin ilk kültüründeki kültürel anlayışın erken yaşlarda ortaya çıktığını ve tipik olarak 5 yaşına kadar kurulduğunu" söyler. "Çocuklar yeni kültürel kalıpları yetişkinlerden daha kolay öğrenirler" der. Küçük çocuklar, hepimizin aynı ve bazı yönlerden farklı olduğumuzu öğrenebilirler. Aslında araştırmalar, çocukların tamamen önyargıdan uzak olmadığını da göstermiştir. Çalışmalar (Palmer 1990; Ramsey ve Myers 1990; Glover 1996), üç yaşındaki çocukların ten, göz ve saç rengi gibi farklılıkları fark ettiklerini göstermiştir. Sosyalleşmelerinin bir parçası olarak çocuklar, kendilerini başkalarıyla karşılaştırarak öz kimliklerini geliştirirler. Bazı gözle görülür benzerlikler ve farklılıklar nedeniyle belirli gruplara ait olduklarını ve diğerlerine ait olmadıklarını öğrenirler. Çevrelerindeki diğer kişilerin nasıl tepki verdiğini ve bu farklılıklara nasıl tepki verildiğini gözlemleyerek, neyin değerli neyin değerli olmadığını görürler. Gözlemlenen farklılıklar hakkında olumlu ya da olumsuz duygular geliştirmeye başlarlar. Bu duygular, bu farklılıkların "iyi" veya "kötü" olup olmadığına ilişkin değerlendirici yargıların temelini oluşturur. $\mathrm{Bu}$ yargılar, olumsuz terimlerle çerçevelendirilirse önyargı haline gelir. Glover (1996), ailenin etkisi, diğer önemli erken çocukluk hizmetleri ve kitle iletişim araçları, çocukların farklılıklara yönelik tutum ve davranışlarını geliştirmede hayati bir rol oynadığını ifade etmektedir. Çocuklar, kademeli sosyalleşme ve kültürleşme süreci yoluyla doğrudan veya dolaylı olarak başkalarına ırk, cinsiyet, yaş, yetenek, din ve kültürel miras temelinde farklı şekilde davranmayı öğrenebilirler.

Çocuklar farklı kültürler içinde doğarlar ve büyüdükleri kültürel değerleri öğrenirler. $\mathrm{Bu}$ öğretiler formal eğitim veya informal eğitim şeklinde gerçekleşir. Kültür konusunda çocuk hem formal hem de informal eğitim ile bilgi sahibi olur. Kültür, kültürel miras, tarih, sanat gibi konularda çocuk hem formal hem de informal eğitim süreçlerinde karşılaşır. İnformal eğitimde kültürel miras aktarımı aile içinde sohbetlerle, dede ve ninenin anlattığı masal ve hikayelerle kuşaktan kuşağa aktarılırken, kadının iş hayatına başlaması, büyük aileden çekirdek aileye dönüşmesi kuşaktan kuşağa kültür aktarımını zorlaştırmıştır. Teknolojik gelişmeler, medyanın insan hayatındaki artan yeri, kuşaklar arasındaki etkileşimi azaltmaya başlamıştır. Bu nedenle aile içinde anlatılan masallar unutulmuş, destanlar yerini film veya dizi filmlere bırakmıştır. Bu nedenle kültürel miras eğitiminde formal eğitimin önemi artmıştır. Tarihi anlamak ve anlatmak, arkeolojiyi öğretmek ve kültürel mirası korumak için çocukların bu alanlarda eğitilmesi oldukça önemli hale gelmiştir (Stone 
ve Molyneaux, 1994; Smardz ve Smith, 2000). Kültürel mirası korumanın birçok yöntemi vardır. Bunlardan birisi de çocuklara tarihsel alanlara ve geleneklere değer vermeyi öğretmektir. Çocukların eğitiminde kullanılacak birçok yöntem geliştirilebilir. Kültürel miras konusundaki eğitimde de çocukların yaş grupları da dikkate alınarak farklı etkinlikler geliştirilebilir. Özellikle her yaşta çocuğun hoşlandığı olayları hikayeleştirerek anlatmak bir yöntem olarak seçilebilir (Riihelä, 2001; Aerila ve Rönkkö, 2015). Masallar veya hikayeler geçmiş yaşanmışlıkları, inançları, duygu ve düşünceleri günümüze taşıyan sanat eserleri gibidir. Gerçekte masallar, efsaneler, destanlar, halk hikayeleri, fikralar somut olmayan kültürel miras öğeleridir. Birleşmiş Milletler tarafından kabul edilen "Somut Olmayan Kültürel Mirasın Korunması Sözleşmesi" ile somut olmayan kültürel mirasın korunması konusunda çok ciddi bir adım atılmıştır (KTB, 2020). Masal, destan, efsane veya halk hikayeleri hem somut olmayan kültürel miras olmaları nedeni ile korunmalıdır, hem de bu yöntem bir bilgi aktarım yolu olarak kullanılabilir. Erken çocukluk evresinde, çocuk ebeveynlerinden veya öğretmenlerinden hikayeler dinlerler. Çocuk ile masal anlatıcısı arasında bir güven ilişkisi vardır (Campbell, 2001). Bu güvenli ortamda çocuğa kültürel miras öğeleri ve korunmasının önemi anlatılabilir. Efsaneler ve destanlar geçmişin tarihi gibidir. Destanlarda ya da efsanelerde geçmişte yaşanan ve toplumları derinden etkileyen savaşlar, göçler, kıtlıkların; kahramanlık ve olağanüstülükler katılarak anlatıldığı tarih olaylarıdır. Her toplumda ve kültürde efsaneler ve destanlar vardır ve toplumlarda derin izler birakan olayları anlatırlar. Çocuklara bu efsane ve destanlar anlatılarak çocuğun bu mirası tanıması, anlaması ve koruması için bilinç oluşturulabilir. Çocuklar dinledikleri masal, öykü, efsane veya destanlar ile geçmişle de bağlar kurar, hayal dünyalarını geliştirirler. Evde veya okulda, ebeveyni veya öğretmeninin okuduğu bir kitap, okuyucu, çocuk ve yazar arasında bir bağ kurar (Langer, 1995; Lukens, 2007; Hade, 2013).

Tarihin öğrenilmesinde olayları hikayeleştirmek, resimli kitaplar kullanarak tarihi anlatmak kullanılan bir yöntemdir (Virta, 2015). Çocuk öğrendiği her bilgiyi, hayal dünyasında bir gerçeklik ile bağdaştırır. Yaşadığı toplumu veya diğer toplumları, benzerlikleri ve farklılıkları ona okunan veya okuduğu kitaplarla öğrenir. Tarih ile ilk tanışıklı̆̆ı; mitolojideki bir tanrı, destanlardaki bir kahraman, efsanedeki bir olay ile olur. O nedenle eğitimciler geçmiş yaşam biçimlerini göstermek, öğrenmeyi geliştirmek ve öğrencilerin motivasyonunu sağlamak için hikâyeleri, efsaneleri destanları veya masalları kullanırlar (Youngs, 2012; Bickford, 2013). Müzelerin oyun ve sosyal etkileşim yolu ile pedagojik eğitimde bir unsur olarak kullanılabileceği de son yıllarda yapılan çalışmalarda ele alınmaktadır (Aerila, Rönkkö ve Grönman, 2016). Müzelerle erken çocukluk döneminde çocukların tanıştırılması ve müzelerin bir öğreti amacı ile kullanılabilecek araçlar olarak uygulanması hem çocuğun öğrenmesini kolaylaştıracak hem de sonraki yaşlarda müze ziyaretlerini de teşvik edecektir.

Yaşanan toplumu anlamak ve toplumsal bağların geliştirilmesini sağlamak için ortak değerlerin yaratılması oldukça önemlidir. Bu değerlerden birisi de ortak dil ve tarih anlayışının geliştirilmesidir. Tarihin hikayeleştirilerek anlatılması çocuğun tarihi anlamasını kolaylaştıracağı gibi kültüre ve kültürel mirasa bağlılığı artırır (Youngs ve 
Serafni, 2011). Destan ve efsanelerin resimleştirilmesi, tarihi gerçeklerin bu öğeler içinde verilmesi tarihi anlamayı ve somutlaştırılmasını kolaylaştırır. Resimli tarih kitapları, çocuk edebiyatının önemli araçlarından birisidir (Youngs, 2010) ve tarihsel kavramları ve olayları anlamak, geçmiş dönem yaşam tarzlarını kavramak, kişiler, olaylar ve mekânlar arası ilişkileri kelimeler, görüntüler ve tasarım parametrelerini kullanarak sunulduğu eserlerdir. Tarih sadece geçmişte yaşanmış ve bitmiş olaylar bütünü değildir, günümüze uzanan ve yansımalarını hissettiğimiz bugünün anahtarıdır. Çocuk dinlediği ya da okuduğu öyküler, masallar, efsaneler, destanlar veya mitler ile hayal dünyasında tarihte yaşanmışlıklarla bugün arasında bir köprü kurar. Tarihi ve kültürü öğrenirken, kültürel değerlerin anlamı ve önemini kavrar. Çocuklar çoğu zaman hikâyelerde sunulan gerçekleri tartışmaya alışık olmayabilirler ve çoğu durumda onları gerçekmiş gibi kabul edebilirler (Serafni, 2014; Youngs ve Serafni, 2011). Bu nedenle çocuklara anlatılar özenle seçilmelidir.

Zaman ve yaşam şekilleri değiştikçe kültürler de değişir, kültürler canlıdır ve her toplumda farklı kültürler bir arada yaşar. Lesourne (1993) kültür öğretisi için ne tür okullara ihtiyacımız olduğunu ve okullarda hangi kültürü öğretmesi gerektiği konusunda bir soru soruyor. Lesourne kültür ve okullar arasındaki ilişkinin iki varsayıma odaklanması gerektiğini ifade ediyor;

- Okulların rolü çağdaş kültürle ilişkiyi güçlendirmektir,

- Okulların katkısı öncelikle önerdiği özel programlarda değil, belirli sayıda farklı alan arasında anlamlı bir ilişki yaratılmasında yatmaktadır.

Ancak, okulların görevinin tek bir kültürü yaymak olduğunu savunmak akılcı değildir. Doğru olanı farklı kültürlerin olduğu gerçeğini çocuklara anlatmak ve farklılıkların zenginlik olduğunu, farklı kültürlere saygı duymanın esas olduğunu göstermektir. Bir cinsiyetin diğer cinsiyetten, bir ırkın diğer ırktan üstün olmadı̆̆ı gibi bir kültürün başka bir kültürden üstün olmadığının çocuklara anlatılması esas olmalıdır.

Okul ve kültürel miras ortamı arasındaki ilişki sanatsal bir ilişkidir ve çocukların yaratıcılıklarını güçlendirir. Çocukların çevrelerinde bulunan tarihsel, kültürel ve doğal mirasından esinlenen sanat projelerine katmak, kimlik gelişimlerine katkıda bulunduğu gibi sanata duydukları ilgiyi de artırmaktadır. Doğal ve kültürel miras öğeleri ile etkileşimleri, yaşadıkları ortamı algılamaları ve anlamalarına yardımcı olmaktadır (Ivon ve Kuscevic, 2013). Çocuklara erken yaşlarda oluşan bu duyarlılıklar, kültürel miras öğelerinin korunması konusuna da katkı sağlamakta ve farkındalıklarını güçlendirmektedir. Okulların, okul öncesi dönemden itibaren temel görevlerinden biri de farklı kültürleri tanıtmak, farkındalık yaratmak, çocukların yaratıcılıklarını geliştirmek, sanat, kültür ve doğal mirası tanıtarak korumalarına yardımcı olmak olduğu söylenebilir. Çünkü kültürel mirasın aktarılması için en önemli kaynaklardan birisi okullardır (Dönmez ve Yeşilbursa, 2014; Uçar, 2014). Eğitimde kültürel farklılıkların çocuklara öğretilmesi hem toplum içi ilişkilerde hem de farklı toplumlarla etkileşimlerde diğerlerini anlamayı kolaylaştırır. Kültürel miras öğelerinin eğitim yolu ile içselleştirilmesi sağlanabilir. 
Okullarda çocuklara kültürel mirasın hem bilişsel hem de sosyal boyutlarda öğretilmesi büyük önem taşır. Okul, tarih, kültürel miras arasındaki ilişkileri anlama ve kavramamıza yardımcı olur. Bireyin kendini ve çevresini anlamaya yardımcı olur. Çocuğun olaylar arasında neden-sonuç ilişkisi kurmasını sağlar ve hem yerel hem de evrensel olmaya hazırlar. Bu öğreti şimdiki zamanla daha iyi başa çıkmak için değil, aynı zamanda "dayanışma"nın geleceğine dair daha iyi karar vermek için önceki olayların derinlemesine anlaşılmasını da destekler (Nanzhao, 1998). Eğitim, yaşadığı toplumun veya dünya kültürel mirasını ve kimliklerini öğrenmesinde çok önemli bir araçtır (Cohen, 2011).

Ridgway (2014) kültürlerin, geleneklerin, toplumdaki ritüellerin veya kurumsal birçok uygulamanın tarihi geçmiş ve bugün ile ilgili olduğunu ifade etmektedir. Çocuk yaşadığı toplumda bu ritüelleri yaşarken öğrenir ve çoğunlukla da olduğu gibi ve mutlak doğrular olarak kabul eder. Vygotsky (1997) kültürel gelişimin "genetik olarak daha karmaşık ve daha yüksek bir davranış biçimini temsil ettiği"ni, "kültürel gelişim sürecinin kendisinin temel orijinal yapıda ve yeni yapıların gelişiminde bir değişiklik olarak anlaşılması gerektiğini" ifade etmiştir.

\section{Kültürel Miras ve Turizm}

Turizm günümüzün en hızlı büyüyen sektörlerinden birisidir. Her geçen yıl hem turist sayısı hem de turizm geliri artmaktadır. Turizmin çeşitlendirilmesi ve yeni turizm alanlarının yaratılması sürdürülebilir turizm için oldukça önemlidir. Turizm çeşitlendirilmesinde en önemli öğelerden birisi de kültür turizmidir. Kültür turizminde doğal ve tarihsel kültürel varlıkların korunması oldukça önemlidir. Kültürel turizmde, gösteri sanatları ve kültür turları, festivaller ve diğer kültürel etkinlikler, tarihi yerler ve anıtlar gibi kültürel öğeler büyük önem taşımaktadır.

Kültür turizmi, tarih ve sosyolojinin önemli bir konusudur ve kültürel coğrafyaya bitişik alanlara ve kültürel hareketlilikleri, kültürel kimlikleri ve farklı gelişim düzeylerindeki toplumlar arasındaki ilişkileri kapsar. Özünde, kültür turizmi, bir turistin bugün ve geçmiş arasında, kendi ülkesi ile diğer ülkeler arasında, gündelik hayat ile farklı kültürlerin hayatları arasında bir yolculuğa çıkmasını sağlar.

Kültür turizmine olan ilgi (Hewison, 1987), uluslararası ve yurtiçi seyahatin büyümesi ve kültürel turizmin 'iyi' bir turizm biçimi olarak tanımlanmasının yol açtığ 1 1980'ler ve 1990'lar boyunca artmaya devam etti, ekonomileri canlandırırken ve kültürün korunmasına yardımcı olmaya başladı (Richards, 2001). Günümüzde turistler "özgün bir deneyim" aramakta ve ziyaret ettiği ülkenin toplumunu diğerlerinden ayıran kendine özgü özellikleri görmek ve tanımak istemektedir. Bu özellikler tarihten gelen, gelenekleri, görenekleri, sanatı ve kültürü içermektedir.

Kültür turizmi uzun zamandır kültüre destek sağlayarak ve turizm için cazibe merkezleri oluşturarak her iki alana da fayda sağladığı görülmüştür. Ancak bu tür sinerjilerin ne ölçüde gerçekleştirildiği ve ayrıca kültür ve turizmin aktif olarak birbirine zarar verip vermeyeceği konusunda bazı sorular mevcuttur (Richards, 2003). Toplumların kültürel zenginliklerini koruması, ortaya çıkarması ve sunması 
ziyaretçileri çekmenin önemli bir yoludur. Farklı kültürleri, sanatı, mimariyi, tarihi ve kültürel mirası, mutfak kültürünü, edebiyatı, müziği ve yaşam tarzlarını, değerleri ile yaşayan kültürleri görmek ve tanımak amaçlı turistlerin beklentisi bu değerlerin korunmasidır (McKercher ve Du Cros, 2002).

Kültür turizmi, turizm pazarında önemli bir büyüme potansiyeli barındırmaktadır. Kültür turizmi varlıkları arasında müzeler, sanat galerileri, tarihi tema parkları, miras alanları ve sanat festivalleri bulunmaktadır. Bununla birlikte, miras alanlarını ziyaret etme ve kültürel faaliyetlere katılma konusundaki turist popülaritesine rağmen, kültür ve miras turizmi olgusuna göreceli olarak çok az detay verilmiştir. Kültür ve miras turizminin uzun vadeli faydalarını maksimize etmek için, bununla birlikte, yeri doldurulamaz kültürel ve miras kaynaklarının korunmasını ve uygun şekilde kullanılmasını sağlayacak etkili yönetim stratejilerinin geliştirilmesine dikkat edilmelidir (Zeppel ve Hall, 1991). Kültür turizminin gelişmesi için kültürel mirasların korunması oldukça önemlidir. Bu mirasın yeniden yaratılması mümkün değildir. Olduğu gibi ve değiştirilmeden korunması gerekir.

\section{YÖNTEM}

\section{Çalışma Modeli}

Araştırmada, okul öncesi öğretmenlerinin kültürel miras eğitimine yönelik görüşlerini belirlemek için nitel araştırma yöntemlerinden durum çalışması kullanılmıştır.

\section{Çalışma Grubu}

Araştırmada nitel araştırma örnekleme yöntemlerinden amaçlı örnekleme yöntemi kullanılmıştır. Amaçlı örnekleme yöntemi kendi içerisinde, aşırı veya aykırı durum örneklemesi, maksimum çeşitlilik örneklemesi, benzeşik örnekleme, tipik durum örneklemesi, kartopu ve zincir örnekleme, ölçüt örnekleme, doğrulayıcı ve yanlışlayıcı örnekleme ve kolay ulaşılabilir durum örnekleme olmak üzere dokuz farklı şekilde gerçekleştirilebilir (Yıldırım ve Şimşek, 2016 s. 123). Bu araştırmada, yakın olan ve erişilmesi kolay olan örnekleme yöntemi olan kolay ulaşılabilir durum örnekleme yöntemi kullanılmıştır. Bu bağlamda araştırmanın çalışma grubunu, Denizli ili merkez ilçelerinde çeşitli kurumlara bağlı, okul öncesi eğitim sınıflarında görev yapan 74 öğretmen oluşturmaktadır. Katılımcıların tümü kadındır. Araştırmaya katılan öğretmenlere ilişkin yaş, eğitim düzeyi, hizmet süresi ve çalışılan kurum türü ile ilgili demografik bilgiler Tablo 1'de belirtilmektedir.

Tablo 1 incelendiğinde, katılımcıların yarısından fazlasının yaşlarının 36-45 yaş aralığında değiştiği görülmektedir ( $\mathrm{n}=42$; \%56.8). Tablo 1'de ayrıca katılımcıların büyük bir bölümünün lisans mezunu olduğu (n=63; \%85.1) ve çoğunluğunun da hizmet sürelerinin on yıl ve üstü (n=54; \%72.97) olduğu anlaşılmaktadır. 
Tablo 1: Çalışma Grubundaki Okul Öncesi Öğretmenlere İlişkin Demografik Bilgiler

\begin{tabular}{|c|c|c|c|}
\hline Kişisel Bilgiler & & $\mathrm{n}$ & $\%$ \\
\hline \multirow{4}{*}{ Yaş } & 24-35 yaş & 25 & 33.7 \\
\hline & 36-45 yaş & 42 & 56.8 \\
\hline & 46 yaş ve üstü & 7 & 9.5 \\
\hline & Toplam & 74 & 100 \\
\hline \multirow{5}{*}{ Eğitim Düzeyi } & Açık öğretim mezunu & 2 & 2.7 \\
\hline & Ön lisans mezunu & 5 & 6.8 \\
\hline & Lisans mezunu & 63 & 85.1 \\
\hline & Yüksek lisans mezunu & 4 & 5.4 \\
\hline & Toplam & 74 & 100.0 \\
\hline \multirow{4}{*}{ Hizmet Süresi } & 1-5 yıl arası & 5 & 6.76 \\
\hline & 6-10 yıl arası & 15 & 20.27 \\
\hline & 10 yıl ve üstü & 54 & 72.97 \\
\hline & Toplam & 74 & 100.0 \\
\hline \multirow{5}{*}{$\begin{array}{l}\text { Çalıştı̆̆ } 1 \\
\text { Türü }\end{array}$} & İlkokullara bağlı anasınıfı & 8 & 10.8 \\
\hline & Bağımsız anaokulu & 61 & 82.4 \\
\hline & Kolej anaokulu & 4 & 5.4 \\
\hline & Özel anaokulu & 1 & 1.4 \\
\hline & Toplam & 74 & 100.0 \\
\hline
\end{tabular}

\section{Veri Toplama Araçları}

Çalışmada veri toplama aracı olarak araştırmacılar tarafından geliştirilen yapılandırılmış görüşme formu kullanılmıştır. Görüşme formu alan yazın incelenmesi yapılarak araştırmanın amaçlarına uygun kavramsal çerçevede oluşturulmuştur. Görüşme formunda yer alan sorular için, konu ile ilgili çalışmaları olan turizm fakültesinden üç öğretim üyesi, okul öncesi bölümünden üç öğretim üyesi ile alanda çalışan üç okul öncesi öğretmeninden uzman görüşü alınmıştır. Görüşme formuna son şekli uzmanlardan gelen öneriler dikkate alınarak verilmiştir. Görüşme formunun son halinde öğretmenlerin demografik bilgilerini içeren kişisel bilgi formu ve araştırmanın amacına uygun 10 açık uçlu 10 kapalı uçlu olmak üzere toplam 20 soru yer almaktadır.

\section{Verilerin Toplanması}

Araştırma verileri öğretmenlerden 2020-2021 güz dönemi Aralık-Ocak aylarında toplanmıştır. Veri toplanması sürecinde Google Form programından yararlanılmıştır. Google Form programı aracıllğıyla oluşturulan form, doldurulabilmesi için katılımcllara elektronik ortamda iletilmiştir.

\section{Verilerin Analizi}

Araştırmadan elde edilen verilerin analizinde betimsel analiz tekniğinden yararlanılmıştır. Betimsel analiz, elde edilen bulguların temalara göre özetlenmesi ve 
yorumlanmasını içerir. Betimsel analizde verilerin hangi temalarda düzenleneceği ve sunulacağı bellidir (Yıldırım ve Şimşek, 2016:239). Bu çalışmada, görüşme sorularına dayalı olarak temalar daha önceden belirlenmiştir.

Araştırma verilerinin analizi için ilk olarak her bir katılımcıdan elde edilen veriler, sorular bazında Excel Programına aktarılmış ve kodlanmıştır. Tüm görüşme metinleri okunarak her soru için temalar belirlenmiş ve kodlanan veriler, ilgili temalarda belirtilmiştir. Daha sonra her bir tema altında yer alan kodların frekansları hesaplanarak tablolaştırılmıştır. Araştırmada, katılımcıların görüşlerini doğru şekilde yansıtabilmek için doğrudan alıntılara da yer verilmiştir. Doğrudan alıntıların paylaşımında katılımcı öğretmenler Ö:1, Ö:2, ... Ö:74 şeklinde kodlanarak ifade edilmektedir.

Araştırmanın güvenirliği için katılımcıların görüşlerinin değerlendirilmesi ile oluşturulan temalar, biri ölçme değerlendirme, ikisi turizm alanında akademik çalışmalar gerçekleştiren 3 öğretim üyesinin görüşüne sunulmuştur. Bu süreçte uzmanlardan gelen öneriler dikkate alınmıştır. Araştırmanın geçerliği için ise nitel araştırmalara uygun olarak veri analiz süreci ayrıntılı bir biçimde açıklanmıştır. Bununla birlikte bulgular hem nicel olarak verilmiş hem de katılımcı ifadelerine yer verilerek nitel olarak bir arada sunulmaktadır.

\section{BULGULAR}

Okul öncesi öğretmenlerinin kültürel miras ile ilgili görüşleri onların bu kavramı nasıl değerlendirdikleri ile ilgili bulgular tablolar halinde sunulmuştur.

Tablo 2: Okul öncesi öğretmenlerinin "kültürel miras" ile ilgili görüşlerinin frekans ve yüzde değerleri

\begin{tabular}{lll}
\hline Okul öncesi öğretmenlerinin “kültürel miras” ile ilgili görüşleri & $\mathrm{n}$ & $\%$ \\
\hline Bir milletin geçmişten günümüze gelen maddi-manevi değerleri & 50 & 48.54 \\
Geleneklerimiz, göreneklerimiz, örf ve adetlerimiz & 22 & 21.36 \\
Milli Değerlerimiz & 17 & 16.50 \\
Evrensel değerler bütünü & 14 & 13.60 \\
TOPLAM & 103 & 100.0 \\
\hline
\end{tabular}

Tablo 2 okul öncesi öğretmenlerinin kültürel miras ile ilgili görüşlerini yansıtmaktadır. Öğretmenlerin kültürel miras ile ilgili en çok bir milletin geçmişten günümüze gelen maddi-manevi değerleridir düşüncesinde oldukları anlaşılmaktadır ( $\mathrm{n}=50 ; \% 48.54)$. Katılımcıların ikinci olarak en çok dile getirdikleri görüş ise kültürel mirası geleneklerimiz, göreneklerimiz, örf ve adetlerimizi kapsadığıdır ( $n=22 ; \% 21.36)$. Gelenek ve görenekler manevi değerlerimiz arasındadır, bazı katılımcılar kültürel miras olarak sadece gelenek ve göreneklere vurgu yapmıştır, bazı katılımcılar ise daha kapsayıcı bir ifade ile tanımlamayı seçmiştir. Tablo 2 incelendiğinde, kültürel mirası milli değerlerimiz ( $\mathrm{n}=17$; \%16.50) olarak değerlendiren bazı katılımcılar onlara yöneltilen bu soruya sadece milli değerlerimizi örnekleyerek yanıt vermişlerdir. Yanıtların \%13.60'1 öğretmenlerin kültürel mirası evrensel değerler bütünü $(n=14$; 
\%13.60) olarak değerlendirdiklerini göstermektedir. Öğretmen görüşlerinden bazıları aşağıda belirtilmektedir:

"Dil, din, tarih, gelenek ve göreneklerimizin yeni nesle aktarılmasıdır." (Ö.11).

"Farkl coğrafyalara ve orada yaşayan insanlara özgü oluşturulmuş her türlü örf, adet, gelenek, yapı, dil öğeleri" (Ö.67)

Tablo 3: Okul öncesi öğretmenlerinin, ülkemizde önemli gördükleri kültürel miras öğeleri hakkındaki görüşlerinin frekans ve yüzde değerleri

\begin{tabular}{llc}
\hline $\begin{array}{l}\text { Okul öncesi öğretmenlerinin, ülkemizde önemli gördükleri kültürel miras } \\
\text { öğeleri hakkındaki görüşleri }\end{array}$ & \% \\
\hline $\begin{array}{l}\text { Doğal ve tarihi alanlar (Ören yerleri), müzeler } \\
\text { Yöresel oyunlar, kıyafetler, yemekler, el sanatları, destanlar, efsaneler, } \\
\text { yazıtlar, halk kahramanları, masallar, türküler } \\
\text { Milli ve manevi değerler }\end{array}$ & 40 & 43.51 \\
Örf-adetler, gelenek-görenekler & 24 & 15.58 \\
Fikri olmayan & 21 & 13.64 \\
Çevre bilinci & 1 & 0.65 \\
Toplam & 1 & 0.65 \\
\hline
\end{tabular}

Tablo 3'te okul öncesi öğretmenlerinin görüşlerine göre ülkemizde önemli gördükleri kültürel miras öğeleri sırasıyla "doğal ve tarihi alanlar ile müzeler" (n=67; \%43.51), "yöresel oyunlar, kıyafetler, yemekler, el sanatları, destanlar, efsaneler, yazıtlar, halk kahramanları, masallar, türküler" ( $n=40 ; \% 25.97)$ ve "milli ve manevi değerler" (n=24; \% 15.58) olduğu görülmektedir. Tablo 3’e göre öğretmen görüşlerinden diğer öne çıkan öğe kategorisi "örf, adetler ve gelenek-görenekler" oluşturmaktadır (n=21; \%13.64). Öğretmenler öğeleri örnekleyerek vermişlerdir. Öğretmenlerin görüşlerinden örneklemek gerekirse;

"Pamukkale-Hierapolis, Kapadokya, Göbeklitepe, Efes Antik Kenti, Ayasofya, İstanbul'da bulunan birçok tarihi alan" (Ö.66)

"Dil, din, gelenek, yaşantl, kıyafetler, sanat, doğal ve tarihi yapılar, türküler, destanlar vb yazılı yazısız somut veya somut olmayan birçok değer" (Ö.20)

Elde edilen yanıtlar öğretmenlerin somut kültürel miras kadar somut olmayan kültürel miras öğelerini de önemli gördüklerini göstermektedir.

Tablo 4 incelendiğinde katılımcıların tamamının okul öncesi dönemde kültürel miras eğitimi verilmesi yönünde görüşe sahip olduğu söylenebilir. Öğretmenlerin bu görüşleri Tablo 4'te dört kategoride belirtilmektedir. Tablo 4' de bu kategoriler sırası ile "verilebilir" ( $\mathrm{n}=61 ; \% 82.43)$, “öğretim ilkelerine göre verilebilir (Seviyelerine ve yaş gruplarına göre yakından uzağa vb.)” (n=6; \%8.11), “kesinlikle verilmeli” (n=5; \%6.76), "çeşitli etkinliklerle (oyun, masal, gezi vb.)" verilebilir ( $\mathrm{n}=2$; \%2.70) şeklinde gösterilmektedir. 
Tablo 4: Okul öncesi öğretmenlerinin kültürel miras eğitiminin okul öncesi eğitimde verilmesine yönelik görüşlerinin frekans ve yüzde dağılımı

\begin{tabular}{lcc}
\hline $\begin{array}{l}\text { Okul öncesi öğretmenlerinin kültürel miras eğitiminin okul öncesi eğitimde } \\
\text { verilmesine yönelik görüşleri }\end{array}$ & $\%$ \\
\hline Verilebilir & 61 & 82.43 \\
$\begin{array}{l}\text { Öğretim ilkelerine göre verilebilir (Seviyelerine ve yaş gruplarına göre } \\
\text { yakından uzağa vb.) }\end{array}$ & 8.11 \\
Kesinlikle verilmeli & 5 & 6.76 \\
Çeşitli etkinliklerle (oyun, masal, gezi vb.) verilebilir. & 2 & 2.70 \\
Toplam & 74 & 100.0 \\
\hline
\end{tabular}

Okul öncesi öğretmenlerinin okul öncesi dönemde kültürel miras eğitimine yer verilmesine yönelik nedenlerinin belirtildiği Tablo 5 incelendiğinde öğretmenlerin toplam 87 görüş belirttiği ve bu görüşlerinin on bir farklı kategoriden oluştuğu görülmektedir.

Tablo 5: Kültürel miras eğitiminin okul öncesi eğitimde verilmesinin nedenlerine yönelik öğretmen görüşlerinin frekans ve yüzde dağllımı

\begin{tabular}{lll}
\hline $\begin{array}{l}\text { Kültürel miras eğitiminin okul öncesi eğitimde verilmesinin nedenlerine } \\
\text { yönelik öğretmen görüşleri }\end{array}$ & $\mathrm{n}$ & \\
\hline Ağaç yaş iken eğilir & 21 & 24.14 \\
Kültürü öğrenmek ve korumak için & 18 & 20.69 \\
Neden belirtilmemiş & 12 & 13.79 \\
Aydınlık bir gelecek için & 8 & 9.20 \\
Temel eğitim & 7 & 8.05 \\
Öğrenme hızlı olduğu için & 6 & 6.90 \\
Ülkeyi ve değerleri tanımak için & 6 & 6.90 \\
Doğa güzelliklerini tanıma ve koruma için & 4 & 4.60 \\
Çocuklar kültürel mirasa karşı ilgili oldukları için & 3 & 3.45 \\
Benlik oluşumuna katkı sağlamak için & 1 & 1.15 \\
Entelektüel bakış açısı için & 1 & 1.15 \\
Toplam & 87 & 100.0 \\
\hline
\end{tabular}

Tablo 5'teki kategoriler içerisinde öğretmenlerin en çok "ağaç yaş iken eğilir" ( $\mathrm{n}=21$; \% 24.14) ve "kültürü öğrenmek ve korumak için" ( $n=18$; \% 20.69) nedenleri ile kültürel miras eğitiminin okul öncesi dönemde verilmesi gerektiği düşüncesinde oldukları söylenebilir. Tablo 5'te ayrıca 12 katılımcının bu konuda görüş belirtmediği de anlaşılmaktadır ( $\mathrm{n}=12 ; \% 13.79)$. Konu ile ilgili katılımcıların belirttiği diğer kategoriler ise "aydınlık bir gelecek için" (n=8; \%9.20), "temel eğitim" (n=7; \%8.05), "öğrenme hızlı olduğu için" (n=6; \%6.90), "ülkeyi ve değerleri tanımak için" (n=6; \%6.90), "doğa 
güzelliklerini tanıma ve koruma için" ( $\mathrm{n=4}$; \%4.60), “çocuklar kültürel mirasa karşı ilgili oldukları için” (n=3; \%3.45), “benlik oluşumuna katkı sağlamak için” (n=1; \%1.15) ve "entelektüel bakış açısı için" (n=1; \%1.15) şeklindedir. Öğretmen görüşlerinden bazıları aşağıda belirtilmektedir:

"Yaş düzeylerine uygun şekilde verilmelidir çünkü ă̆aç yaşken eğilir" (Ö.15)

“Öğrencilerin kültürünü ve tarihini bilmesi, kültürün korunması gerektiğgi bilincinin oluşturulması için" (Ö.8)

"Bu de ğerlerle büyüyen çocuklar ileride daha çok araştıran, kıymet bilen, doğa sevgisi olan ve tarihi değerlerin kıymetini bilen-koruyan bireylere dönüşürler, çünkü bu değerler sonradan kazanılmaz erken çocuklukta ailede ya da okulda kazanılır." (Ö.49)

Tablo 6: Okul öncesi öğretmenlerinin kültürel miras eğitimine yönelik etkinlik yapma durumlarının frekans ve yüzde dağılımı

\begin{tabular}{lcc}
\hline $\begin{array}{l}\text { Okul öncesi öğretmenlerinin kültürel miras eğitimine yönelik etkinlik } \\
\text { yapma durumları }\end{array}$ & $\%$ \\
\hline Etkinlik yapıyor & 74 & 100.0 \\
Toplam & 74 & 100.0 \\
\hline
\end{tabular}

Tablo 6'da katılımcıların tümünün çocuklar ile kültürel miras eğitimine yönelik etkinlik yaptıkları anlaşılmaktadır. Konu ile ilgili en çok yaptırdıkları ilk üç etkinlik Şekil 1'de belirtilmektedir. Şekil 1 incelendiğinde, okul öncesi öğretmenlerin kültürel miras eğitiminde sanat etkinliği, fen etkinliği, matematik etkinliği, Türkçe etkinliği, oyun etkinliği, okuma yazma hazırlık etkinliği, alan gezisi ve drama etkinlikleri yaptırdıkları anlaşılmaktadır.

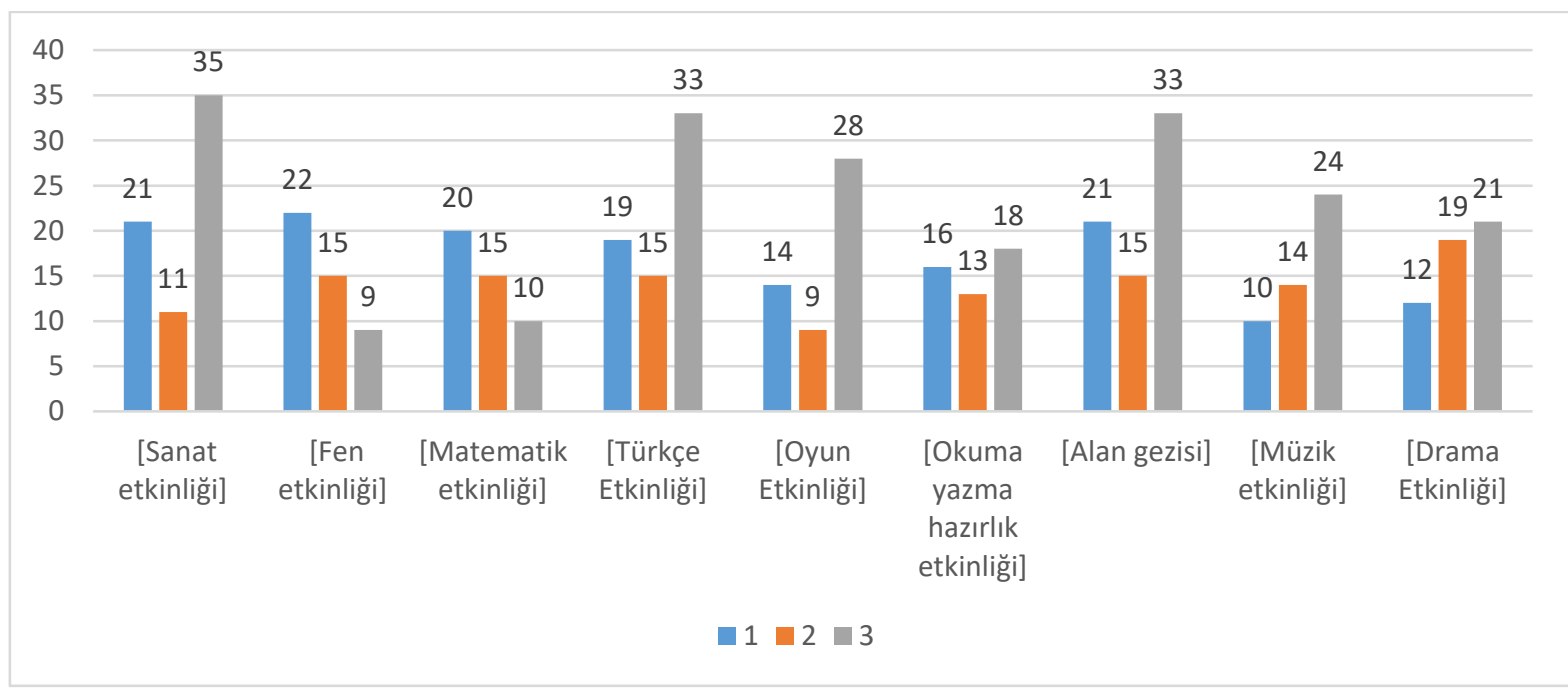

Şekil 1: Okul öncesi öğretmenlerinin kültürel miras eğitimine yönelik en sık yaptıkları ilk üç etkinlik türleri

Şekil 1'e göre yapılan etkinliklerden birinci sırada en çok tercih edilen etkinliğin fen etkinliği $(n=22)$ sonrasında ise sanat etkinliği $(n=21)$ ve alan gezisi $(n=21)$ olduğu görülmektedir. Şekil 1'e göre öğretmenlerin ikinci sırada yaptırdıkları etkinliklerde ilk sırada drama ( $n=19)$, üçüncü sırada ise en çok tercih edilen etkinliğin sanat etkinliği 
( $n=35)$ olduğu söylenebilir. Şekil 1'de öğretmenlerin konu ile ilgili en az tercih ettikleri etkinlikler birinci sırada müzik etkinliği $(n=10)$, ikinci sırada oyun etkinliği $(n=9)$, üçüncü sırada ise fen etkinliği $(n=9)$ olarak görülmektedir.

Tablo 7: MEB Okul öncesi eğitim programının, kültürel miras eğitimine yönelik beklentileri karşılama ile ilgili öğretmen görüşlerinin frekans ve yüzde dağılımı

\begin{tabular}{lll}
\hline & $\mathrm{n}$ & $\%$ \\
\hline Evet karşıllyyor & 40 & 54.5 \\
Hayır, karşılamıyor & 34 & 44.5 \\
Toplam & 74 & 100.0 \\
\hline
\end{tabular}

Tablo 7'ye göre katılımcıların yarısından fazlasının ( $n=40 ; \% 54.5)$ eğitim programının kültürel miras eğitiminde beklentilerini karşıladığı görülürken, 34 katılımcının (\%44.5) konu ile ilgili beklentilerini karşılamadığı anlaşılmaktadır.

Tablo 8: MEB Okul öncesi eğitim programının, kültürel miras eğitimine yönelik beklentileri hangi yönleri ile karşıladığı ile ilgili öğretmen görüşlerinin frekans ve yüzde dağılımı

\begin{tabular}{lll}
\hline Okul Öncesi Eğitim Programının Karşıladığı Ö̆̆retmen Beklentileri & $\mathrm{n}$ & $\%$ \\
\hline Programın esnek olmasından & 13 & 37.14 \\
Programda yer alan etkinlik türleri açısından & 8 & 22.86 \\
Programda yer alan değerler eğitimi açısından & 5 & 14.29 \\
Programda yer alan kazanım ve göstergeler açısından & 4 & 11.43 \\
Programın içeriği bakımından & 3 & 8.57 \\
Konu ile ilgili plan hazırlama açısından & 1 & 2.86 \\
Belirtilmemiş & 1 & 2.86 \\
Toplam & 35 & 100.0 \\
\hline
\end{tabular}

Katılımcların, okul öncesi dönemde kültürel miras eğitimi için MEB okul öncesi eğitim programının beklentilerini karşıladığı yönlerinin gösterildiği Tablo 8 incelendiğinde öğretmenlerin toplam 35 görüş belirttiği ve bu görüşlerinin yedi farklı kategoriden oluştuğu görülmektedir. Tablo $8^{\prime}$ deki kategoriler içerisinde öğretmenlerin en çok "programın esnek olmasından" ( $\mathrm{n}=13$; \%37.14) dolayı programın kültürel miras eğitimi için beklentilerini karşıladığı söylenebilir. Tablo $8^{\prime}$ de ayrıca öğretmenlerin "programda yer alan etkinlik türleri açısından" ( $\mathrm{n}=8 ; \% 22.86)$, "programda yer alan değerler eğitimi açısından" (n=5; \%14.29), "programda yer alan kazanım ve göstergeler açısından" ( $\mathrm{n}=4$; \% 11.43), "programın içeriği bakımından" $(\mathrm{n}=3$; \% 8.57) ve "konu ile ilgili plan hazırlama açısından" ( $\mathrm{n}=1 ; \% 2.86)$ beklentilerini karşıladığını gösteren kategorilerde bulunmaktadır. Öğretmen görüşlerinden bazıları aşağıda belirtilmektedir:

"Esnek bir program. İstediğimiz şekilde hareket edebiliyoruz." (Ö.67) 


\section{"Programda kendi kültürümüzü ve diğer kültürleri tanımayla ilgili kazanım bulunmaktadır. Ele aldığım konuya göre bu kazanıma yönelik etkinlikler üretiyorum." (Ö.8)}

Tablo 9: MEB Okul öncesi eğitim programının, kültürel miras eğitimine yönelik öğretmen beklentilerini karşılayabilmesi için programın hangi öğelerinin desteklenmesi ile ilgili öğretmen görüşlerinin frekans ve yüzde dağılımı

\begin{tabular}{lll}
\hline Okul Öncesi Eğitim Programının Desteklenmesi Gereken Öğeleri & $\mathrm{n}$ & $\%$ \\
\hline Konu ile ilgili kazanım ve göstergeler oluşturulmalı & 4 & 66.67 \\
Kavramlar oluşturulmalı & 2 & 33.33 \\
Toplam & 6 & 100.0
\end{tabular}

Tablo 9'a göre öğretmenlerin bu görüşlerinin iki kategoride toplandığg görülmektedir. $\mathrm{Bu}$ kategoriler "konu ile ilgili kazanım ve göstergelerin oluşturulması" ( $\mathrm{n}=4$; \% 66.67) ve "kavramların oluşturulması" (n=2; \% 33.33) şeklinde Tablo 9' da ifade edilmiştir. Öğretmen görüşlerinden biri aşağıda belirtilmektedir:

“Konu ile ilgili daha fazla amaç kazanım eklenebilir." (Ö.12)

Tablo 10: Okul öncesi öğretmenlerinin programlarında kullanmak üzere seçtikleri Denizli ilinde yer alan kültürel miras öğelerinin frekans ve yüzde dağılımı

\begin{tabular}{|c|c|c|}
\hline $\begin{array}{l}\text { Okul öncesi öğretmenlerinin programlarında kullandıkları Denizli ilinde yer } \\
\text { alan kültürel miras öğeleri }\end{array}$ & $\mathrm{n}$ & $\%$ \\
\hline Zeybek Oyunu & 53 & 13.02 \\
\hline Atatürk Etnografya Müzesi ve Eserleri & 51 & 12.53 \\
\hline Pamukkale Ören Yeri & 43 & 10.57 \\
\hline Keşkek Yemeği & 34 & 8.35 \\
\hline Bardakçllık ve çömlekçilik geleneği & 33 & 8.11 \\
\hline Hierapolis Antik Kenti ve Müzesi & 29 & 7.13 \\
\hline Leodikya Antik Kenti & 29 & 7.13 \\
\hline Denizli Konağ & 28 & 6.88 \\
\hline Kaleiçi Tarihi Çarşısı & 22 & 5.41 \\
\hline Buldan kumaş ve dokuması & 21 & 5.16 \\
\hline Denizli Lisesi & 15 & 3.69 \\
\hline Buldan Tarihi Evleri & 12 & 2.95 \\
\hline Keloğlan Mağarası & 10 & 2.46 \\
\hline Çalg1 yapımcılığı geleneği & 9 & 2.21 \\
\hline Kaklık Mağarası & 8 & 1.97 \\
\hline Akhan Kervansarayı & 5 & 1.23 \\
\hline Sudan koyun geçirme geleneği & 5 & 1.23 \\
\hline Toplam & 407 & 100.0 \\
\hline
\end{tabular}


Tablo 10'da okul öncesi öğretmenlerinin programlarında kullandıkları Denizli ilinde yer alan kültürel miras öğeleri gösterilmektedir. Tablo 10'a göre okul öncesi öğretmenlerinin en fazla kullandıkları kültürel miras öğesi Zeybek oyunu ( $\mathrm{n}=53$; \%13.02) ve Atatürk Etnografya Müzesi ve Eserleridir ( $\mathrm{n}=51$; \%12.53). Tablo 10'da öğretmenlerin programlarında en az yer verdikleri kültürel miras öğeleri ise Akhan Kervansarayı ( $\mathrm{n}=5 ; \% 1.23)$ ve sudan koyun geçirme geleneğidir ( $\mathrm{n}=5 ; \% 1.23)$.

Tablo 11: Okul öncesi öğretmenlerinin kültürel miras eğitimi için materyal kullanma durumlarının frekans ve yüzde dağılımı

\begin{tabular}{llc}
\hline Öğretmenlerin materyal kullanma durumları & $\mathrm{n}$ & $\%$ \\
\hline Evet & 68 & 91.89 \\
Hayır & 6 & 8.11 \\
Toplam & 74 & 100.0 \\
\hline
\end{tabular}

Tablo 11'e göre katılımciların çoğunluğunun ( $\mathrm{n}=68$; \%91.89) materyal kullandığı, 6 katılımcının (\%8.11) konu ile ilgili materyal kullanmadığı anlaşılmaktadır. Materyal kullanan katılımcıların kullandıkları materyal türleri Tablo 12'de gösterilmektedir.

Tablo 12: Okul öncesi öğretmenlerinin kültürel miras eğitimi için tercih ettikleri materyallerin frekans ve yüzde dağılımı

\begin{tabular}{lll}
\hline Tercih edilen materyaller & $\mathrm{n}$ & $\%$ \\
\hline Yöresel eşyalar (kıyafetler, yiyecekler, çömlek, tahta kaşık, Buldan bezi vb.) & 46 & 31.29 \\
Görsel materyaller (fotoğraf, afiş vb.) & 28 & 19.05 \\
Videolar & 15 & 10.20 \\
Müzik & 12 & 8.16 \\
Maketler & 10 & 6.80 \\
Kitaplar, dergiler, hikâye & 7 & 4.76 \\
Belirtilmemiş & 6 & 4.08 \\
Seramik malzemeleri (çini, kil, toprak, oyun hamuru, tuz vb.) & 5.44 \\
Artık materyaller & 8 & 2.72 \\
Kumaş & 4 & 2.72 \\
Kırtasiye malzemeleri & 4 & 2.04 \\
Ahşap materyaller & 4 & 0.68 \\
Bayrak & 3 & 0.68 \\
Oyun materyalleri & 1 & 0.68 \\
Koleksiyon örnekleri & 1 & 0.68 \\
Toplam & 100.0
\end{tabular}

Tablo 12 incelendiğinde, katılımcların kültürel miras eğitimi kapsamında 15 farklı kategoride materyal kullandıkları görülmektedir. Tablo 12'ye göre öğretmenlerin en çok kullandıkları materyallerin "yöresel eşyalar" $(\mathrm{n}=46$; \%31.29) ve "görsel materyaller" olduğu (n=28; \%19.05), en az kullandıkları materyallerin ise "ahşap 
materyaller" (n=1; \%0.68), “bayrak” ( $n=1 ; \% 0.68)$, “oyun materyalleri” ( $n=1 ; \% 0.68)$ ve "koleksiyon örnekleri" (n=1; \%0.68) olduğu söylenebilir.

Tablo 13: Okul öncesi öğretmenlerinin kültürel miras eğitimi için tercih ettikleri materyallerin nasıl temin edildiğine yönelik frekans ve yüzde dağılımı

\begin{tabular}{llc}
\hline $\begin{array}{l}\text { Okul öncesi öğretmenlerinin kültürel miras eğitimi için tercih ettikleri } \\
\text { materyalleri temin etme kaynakları }\end{array}$ & $\%$ \\
\hline Kendi imkânlarımla temin ediyorum & 49 & 39.20 \\
Ebeveynlerden temin ediyorum & 39 & 31.20 \\
Okulun imkânlarını kullanıyorum & 20 & 16.00 \\
Tanıdıklarımdan temin ediyorum & 13 & 10.40 \\
Yetkili kurumlardan temin ediyorum & 2 & 1.60 \\
Belirtilmemiş & 2 & 1.60 \\
Toplam & 125 & 100.00 \\
\hline
\end{tabular}

Öğretmenlerin kültürel miras eğitimi için kullandıkları materyalleri hangi kaynaklardan temin ettikleri Tablo 13'te gösterilmektedir. Tablo 13'te katılımcıların materyal temininde beş farklı kaynak kullandığı söylenebilir. Bu kaynakların kullanım sıklıkları sırası ile "kendi imkânları" ( $\mathrm{n}=49$; \%39.20), "ebeveynlerden temin etme" $(\mathrm{n}=39 ; \% 31.20)$, "okulun imkanları" ( $\mathrm{n}=20 ; \% 16.00)$, "tanıdık vasitasiyla temin etme" $(\mathrm{n}=13 ; \% 10.40)$ ve "yetkili kurumlardan temin etme" ( $\mathrm{n}=2 ; \% 1.60)$ şeklindedir. İki katılımcı kullandıkları materyalleri temin etme kaynağını belirtmemiştir ( $\mathrm{n}=2 ; \% 1.60)$.

Tablo 14: Okul öncesi öğretmenlerinin kültürel miras eğitiminde problem ile karşılaşma durumlarının frekans ve yüzde dağılımı

\begin{tabular}{llc}
\hline & $\mathrm{n}$ & $\%$ \\
\hline Evet & 52 & 70.3 \\
Hayir & 22 & 29.7 \\
Toplam & 74 & 100 \\
\hline
\end{tabular}

Tablo 14'te öğretmenlerin, kültürel miras eğitiminde problemle ile karşılaşma durumları belirtilmektedir. Tablo 14'e göre katılımcıların çoğunluğunun ( $=52 ; \% 70.3)$ problem yaşadı̆̆ı, 22 katılımcının (\%29.7) okul öncesi dönem kültürel miras eğitiminde problem yaşamadığı anlaşılmaktadır.

Tablo 15: Okul öncesi öğretmenlerinin kültürel miras eğitiminde karşılaştıkları problemlerin frekans ve yüzde dağılımı

\begin{tabular}{lcc}
\hline Okul öncesi öğretmenlerinin kültürel miras eğitiminde karşılaştıkları problemler & $\mathrm{n}$ & $\%$ \\
\hline Yeterli materyal bulamıyorum. & 37 & 34.26 \\
Ekonomik sıkıntılar yaşıyorum. & 20 \\
Kalabalık ve küçük sınıf gibi fiziksel koşullar açısından dezavantajlı bir okulda çalıştım. & 14 & 12.96 \\
Ailelerden bu konuda yeteri kadar destek göremiyorum. & 14 & 12.96
\end{tabular}


Okul öncesi eğitim programındaki kazanım ve göstergelerden dolayı konuya yönelik etkinlik $12 \quad 11.11$ yaptıramiyorum.

Konu ile ilgili yeterli bilgi sahibi değilim. $\quad 5 \quad 4.63$

Çeşitli nedenlerden (Küçük yaş grubu, kalabalık sınıf mevcudu vb.) 43.70

$\begin{array}{ll}\text { Okul idaresinden bu konuda yeterli destek göremiyorum. } & 2.85\end{array}$

Toplam 108100.0

Tablo 15 incelendiğinde öğretmenlerin okul öncesi dönemde verilecek kültürel miras eğitiminde en çok karşılaştıkları problemlerin "yeterli materyal bulamaması" (n=37; \%34.26) ve "ekonomik sıkıntılar" ( $\mathrm{n}=20$; \%18.52) olduğu söylenebilir. Öğretmenlerin görüşlerine göre, "kalabalık ve küçük sinıf gibi fiziksel koşullar" (n=14; \%12.96), "ailelerden yeteri kadar destek almama" ( $\mathrm{n}=14$; \%12.96), "okul öncesi eğitim programındaki kazanım ve göstergelerden dolayı konuya yönelik etkinlik yapamama" ( $\mathrm{n}=12 ; \% 11.11)$, "konu ile ilgili yeterli bilgi sahibi olmama" (n=5; \%4.63) gibi durumlarda okul öncesi dönemde kültürel miras eğitiminde karşılaşılan problemler arasindadir.

Tablo 16: Okul öncesi öğretmenlerinin kültürel miras eğitiminde aile katılım etkinliklerine yer verme durumlarının frekans ve yüzde dağılımı

\begin{tabular}{lll}
\hline & $\mathrm{n}$ & $\%$ \\
\hline Evet & 66 & 89.19 \\
Hayır & 8 & 10.81 \\
Toplam & 74 & 100 \\
\hline
\end{tabular}

Tablo 16'ya göre katılımcıların 66'sının (\%89.19) kültürel miras eğitiminde aile katılım etkinliklerine yer verdiği, 8 katılımcının (\%10.81) kültürel miras eğitiminde aile katılım çalışmaları gerçekleştirmediği anlaşılmaktadır.

Tablo 17: Okul öncesi öğretmenlerinin kültürel miras eğitiminde yer verdikleri aile katılım etkinliklerinin frekans ve yüzde dağılımı

\begin{tabular}{llc}
\hline $\begin{array}{l}\text { Okul öncesi öğretmenlerinin kültürel miras eğitiminde yer verdikleri aile } \\
\text { katılım etkinlikleri }\end{array}$ & $\mathrm{n}$ \\
\hline Evlere etkinlik gönderilmesi & 63 & 39.87 \\
Ailelerin sınıfa davet edilmesi & 54 & 34.18 \\
Ailelere konu ile ilgili bilgilendirici yazıların gönderilmesi (afiş, broşür vb.) & 32 & 20.25 \\
Ailelere konu ile ilgili seminer verilmesi & 6 & 3.80 \\
Belirli gün ve haftaları kullanma & 2 & 1.27 \\
Aile katılımlı alan gezisi düzenleme & 1 & 0.63 \\
Toplam & 158 & 100.0 \\
\hline
\end{tabular}

Tablo 17'ye göre öğretmenlerin aile katılım etkinliklerinde en çok "evlere etkinlik göndermesi" olduğu söylenebilir ( $\mathrm{n}=63$; \%39.87). Bununla birlikte Tablo 17 'de 
öğretmenlerin aile katılım etkinlikleri olarak "ailelerin sınıfa davet edilmesi" (n=54; \%34.18), "ailelere konu ile ilgili bilgilendirici yazıların gönderilmesi” (afiş, broşür vb.) (n=32; \%20.25), “ailelere konu ile ilgili seminer verilmesi" (n=6; \%3.80) şeklinde uygulamalar yaptıkları da görülmektedir.

Tablo 18: Okul öncesi öğretmenlerinin kültürel miras eğitimi ile ilgili projede görev alma durumlarının frekans ve yüzde dağılımı

\begin{tabular}{lll}
\hline & $\mathrm{n}$ & $\%$ \\
\hline Hayır & 70 & 94.59 \\
Evet & 4 & 5.41 \\
Toplam & 74 & 100.0 \\
\hline
\end{tabular}

Tablo 18'e göre katılımcıların çoğunluğunun (n=70; \%94.59) konu ile ilgili herhangi bir projede görev almadığı anlaşılmaktadır. Projelerde görev alan öğretmenlerin görev aldıkları projeler Tablo 19' da gösterilmektedir.

Tablo 19: Okul öncesi öğretmenlerinin kültürel miras eğitimi ile ilgili görev aldıkları projelerin frekans ve yüzde dağılımı

\begin{tabular}{lcc}
\hline Görev alınan projeler & $\mathrm{n}$ & $\%$ \\
\hline MEB Çalıştay (katılımcı) & 2 & 50 \\
TÜBİTAK projesi (uzman) & 1 & 25 \\
Okul İçi Proje & 1 & 25 \\
Toplam & 4 & 100.0
\end{tabular}

Tablo 19 incelendiğinde iki öğretmenin kültürel miras eğitimi ile ilgili çalıştayda katılımcı olduğu (n=2; \%50), bir öğretmenin TÜBİTAK projesinde uzman olarak görev aldığı $(n=1 ; \% 25)$, bir öğretmenin ise okul içi projede görev aldığı anlaşılmaktadır (n=1; $\% 25)$.

Tablo 20: Okul öncesi öğretmenlerinin kültürel miras eğitimi ile ilgili hizmet içi eğitim alma durumlarının frekans ve yüzde dağılımı

\begin{tabular}{llc}
\hline & $\mathrm{n}$ & $\%$ \\
\hline Hayir & 62 & 83.78 \\
Evet & 12 & 16.22 \\
Toplam & 74 & 100.0 \\
\hline
\end{tabular}

Tablo 20' de öğretmenlerinin çoğunluğunun (n=62; \%83.78) konu ile ilgili hizmet içi eğitim almadıkları söylenebilir. Tablo 20'de hizmet içi eğitim aldığını ifade eden 12 katılımcının (\%16.22) aldıkları eğitim içerikleri Tablo 21'de gösterilmektedir. 
Tablo 21: Okul öncesi öğretmenlerinin kültürel miras eğitimi ile ilgili eğitimlerin içeriğine yönelik frekans ve yüzde dağılımı

\begin{tabular}{lll}
\hline Ĕ̆itim içerikleri & $\mathrm{n}$ & $\%$ \\
\hline Müze Eğitimi & 5 & 41.67 \\
Müze Eğitimi (Online) & 5 & 41.67 \\
Masal Anlatıcllğı & 2 & 16.67 \\
Toplam & 12 & 100.0 \\
\hline
\end{tabular}

Tablo 21 incelendiğinde beş öğretmenin kültürel miras eğitimine yönelik müze eğitimi aldığ 1 ( $n=5 ; \% 41.67)$, beş öğretmenin yine müze eğitimi ama online olarak aldığ görülmektedir ( $\mathrm{n}=5$; \%41.67). Tablo 21'de ayrıca iki öğretmenin masal anlatıcllı̆ eğitimine katıldığı anlaşılmaktadır ( $\mathrm{n}=2$; \%16.67).

\section{TARTIŞMA, SONUÇ VE ÖNERILER}

Denizli' de küçük çocuklarla çalışan 74 okul öncesi eğitimi öğretmeninin kültürel miras eğitimine ilişkin görüşlerinin ele alındığı bu çalışmada, öğretmenlerin yaklaşık yarısının kültürel miras denildiğinde "bir milletin geçmişten günümüze gelen maddi ve manevi değerleri" düşündükleri ortaya konulmuştur. Bunun yanı sıra, "gelenek, görenek, örf ve adetler", "milli değerler" ve "evrensel değerler" gibi farklı cevaplar verilmiştir. Avcı ve Memişoğlu (2016) tarafından yapılan çalışmada 34 sosyal bilgiler öğretmeni de kültürel mirası, maddi-manevi değerler, geçmişten günümüze kalmış eserler ve evrensel değerler olmak üzere çeşitli cevaplar verilmiştir. Farklı alanlardan olan öğretmenlerin kültürel mirasa yönelik çok yönlü bakış açısı önem taşımaktadır. Eğitimi ele alırken kültürle eğitim arasındaki ilişkiyi dikkate almak gerekir. Kültürler renkler gibidir ve çok farklı tonları vardır. Kültürün bir yanında geçmiş ve geçmiş ile bağlar, bir yanında da o an yaşayan ve yeni kültürler yaratan insan vardır. Kültür statik değildir, değişir, farklılaşır. Kültür geçmişle gelecek içinde bugünü de içine alan hayatımızı kolaylaştıran, birlikte barış içinde yaşamamıza olanak sağlayan, birikmiş bilgiler, gelenekler, değerler, inançlar ve davranış kalıpları sistemi olarak tanımlanabilir (Ogbu, 1989).

Teknolojik gelişmelere paralel olarak kadının iş hayatına katılması, büyük ailelerin yerini çekirdek aileye bırakması, televizyon ve son zamanlarda sosyal medyanın aile hayatındaki yerinin artması aile içindeki kültür aktarımını da zayıflatmıştır. Aile içinde anlatılan masalar, destanlar, halk hikâyeleri yerini izlenen filmler ve dizi filmlere bırakmıştır. Aile içindeki kültür aktarımı zayıflamış yerini kitle kültürü ve popüler kültür olarak tanımlayabileceğimiz ancak o toplum içinde üretilmeyen; dışarıdan ve çoğunlukla da ticari nedenlerle ve medya yolu ile geniş kitleleri etkileyen bir kültür almıştır. Bu noktada okullarda kültürel miras konusunda verilen eğitimin önemi artmıştır. Aile içinde zayıflayan kültürel etkileşim ve kültür aktarımının yerini örgün eğitim almalıdır.

Bu araştırmaya katılan öğretmenler, Türkiye'de önemli gördükleri altı kültürel miras öğesini belirtmişlerdir. Bu öğeler içerisinde en çok söylenilen "doğal ve tarihi alanlar 
(ören yerleri), müzeler" olmuştur. Katılımcllardan biri herhangi bir miras öğesi belirtmemişken biri de "çevre bilinci" şeklinde cevap vermiştir. Bu bağlamda, öğretmenlerin büyük bir çoğunluğunun kültürel miras öğeleri ile ilgili bilgi sahibi oldukları söylenebilir. Konu ile ilgili olmayan iki yanıt da öğretmenlerin yaşadıkları il, coğrafi bölge ve ülke çağında kültürel miras öğelerine ilişkin bilgilerinin artması gerektiği şeklinde değerlendirilebilir.

Öğretmenlerin tamamı, farklı ifade şekillerini tercih etse de kültürel miras eğitiminin okul öncesi dönemde verilebileceğini ifade etmiştir. Ayrıca öğretmenler kültürel miras eğitimine yönelik etkinlikler yaptıklarını da ifade etmişlerdir. Bu bulgu, öğretmenlerin okul öncesi eğitim programında kültürel miras eğitiminin yer almasına yönelik destekleyici tutumlarını ortaya koyması açısından önem taşımaktadır. Kültürel miras eğitiminde yeni materyallerin mevcut müfredata entegre edilmesi veya miras kaynaklarının diğer konuların öğretimini kolaylaştırmak için kullanıldı̆̆ı yenilikçi öğretim yaklaşımlarının kullanılması etkili olsa bile, müfredatın kendisi önemli bir rol oynamaya devam etmektedir (Badran, 2011). Hunter (1988), kültürel miras eğitimini bir müfredata dahil etmenin en iyi yolunun, tüm müfredat konularının miras eğitiminin temelini oluşturduğu mevcut müfredat materyalleri ile entegrasyon yoluyla olabileceğini savunmaktadır. Çok kültürlü toplumlarda miras eğitimini eğitim müfredatına entegre etmek, sürdürülebilir mirasın korunmasını sağlamak için kritik öneme sahip bir konudur. Sürdürülebilir mirasın korunması için eğitimin önemi nedeniyle, mirasın eğitim sisteminde nasıl öğretildiğine dikkat etmek zorunludur. Barghi ve meslektaşları (2017) zengin bir kültürel mirasa sahip çok kültürlü bir ülke olan Malezya'da eğitim müfredatının mirasa ilişkin farkındalık ve saygı duygusunu ne ölçüde geliştirdiğini belirlemek için Malezya'nın yeni ilkokul müfredatını araştırmış ve sonuçlar Malezya'nın somut olmayan kültürel mirasına tarih, sanat ve müzik eğitimi gibi bazı temel konularda odaklandığını ortaya koymuştur. Lusted (2012) çocukların kimlik duygusunun yaşamın ilk yıllarında geliştiğini ifade etmektedir. Bu yüzden de okul öncesi eğitim kurumlarında kültür, tarih ve farklılıklar üzerinde durmak çocuğun gelişimi için oldukça önemlidir.

Öğretmenler, okul öncesinde kültürel miras eğitimine yer verilmesinin nedenleri arasında ilk iki sırada; okul öncesi dönemin sonraki yıllara etkisini ortaya koyarak (Ağaç yaş iken eğilir) ve kültürün korunmasındaki önemine dikkat çekerek cevap vermişlerdir. Kailash (2001) okul öncesi dönemden itibaren müfredatta kültürel miras ile ilgili konuların yer alması gerektiğini ifade etmiştir. Nitekim yaşamın ilk yıllarında çocuklar, hızlı öğrenmekle birlikte çevrelerine karşı da duyarlıdırlar. Kültürel miras ile ilgili de eğer gerekli uyarın ve imkân sağlanamazsa, çocuklar kendi kültürel miraslarına karşı ilgisiz kalabilirler. Konu ile ilgili yapılacak birçok etkinlik (Örnek olarak, sanatsal ve kültürel açıdan ilgi çekici yerlere düzenleyeceği ziyaretler veya sanatçılar, müzisyenlerle bir araya gelmeleri, kutlama, festival gibi etkinliklerin düzenlenmesi vb.) ilgiyi artırabilir, kalıcı öğrenmeyi destekleyebilir (ACESE, 2009; Fleer ve Robbins, 2007). Bu çalışmada, öğretmenlerin 12'si okul öncesi eğitimde kültürel mirasın yer almasının nedeni olarak herhangi bir görüş belirtmemişlerdir. $\mathrm{Bu}$ da öğretmenlerin konu ile ilgili bilgilendirilmesinin önemini ortaya koyan 
bulgulardan biridir. Kültürel mirası korumak için çocukta tarih bilincinin geliştirilmesi, geçmişi anlaması ve saygı duyması oldukça önemlidir. Bir şeyi korumak için ona saygı duymak gerekir. Somut veya soyut olsun kültürel miras öğelerinin birer değer olduğunun çocuğa öğretilmesi gerekir. Kültürel miras öğelerinin sadece bir topluma değil, insanlığa ait değerler olduğu ve korunması gerektiğinin anlaşılması oldukça önemlidir.

Öğretmenler, kültürel miras eğitimine yönelik olacak en sık fen, sanat ve alan gezisi etkinliği, en az ise müzik, oyun ve fen etkinliklerini yaptırdıkları ortaya konulmuştur. $\mathrm{Bu}$ bulgu doğrultusunda öğretmenlerin her etkinlik türünde kültürel mirasa yönelik konuları işleyebileceklerine yönelik bilgi ve deneyimlerinin artması gerektiği söylenebilir. Zengin öğrenme ortamlarının bir gereği olarak tüm etkinlik türlerine dengeli bir şekilde yer verilmelidir. Çocukların çevrelerindeki kültürel miras değerlerini öğrenebilmesi veya içlerinde öğrenme güdüsünü canlandırması, etkileşimli, bütünleştirici öğrenme metotları ile mümkün olabilir (Stevanović, 2002). Çocuklar, kültürel değerleri tüketen değil aynı zamanda üreten bireyler olarak da yetiştirilmelidir. Okullar çocuklara sadece kültürün veya kültürel mirasın anlatıldığı yerler değil aynı zamanda bu olguların yaşandığı yerler olarak da görülmeli ve yapılandırılmalıdır. Bu hedeflere ulaşmak için yaparak, yaşayarak, aktif öğrenme yöntemi kullanılmalıdır (Terhart, 2001). Kültürel mirası öğrenmenin ya da öğretmenin çok farklı yol ve yöntemleri bulunabilir. Kültürlerin farklı olması gibi öğretme modelleri de farklı olabilir. Örnek olarak, müzeler kültürel mirası öğretmenin en önemli araçlarından birisi olabilir. Müzelerde geçmişe ait çok sayıda öğe bulunur. Ancak müzelerin de bu amaca uygun bir sunum yapması sağlanabilir. Tarihi kalıntılar, arkeolojik alanlar da bu mirası öğretmenin ana öğeleri arasında yer alabilir (Putz-Plecko, 2008). Okul öncesi eğitimde kültürel miras öğretisine tarihsel, toplumsal, etnik ve inanç gibi çeşitli bakış açılardan yaklaşılabilir. Okul öncesi çocuklarında kültürel miras eğitimi sanat ve beceri temelli konuları ele alarak yapılabilir. Bu öğreti ile amaç sadece tarihi öğretmek veya tarih bilincinin sağlanması değil, aynı zamanda yaşam tarzı, sanat, kültür gibi birçok konuyu içeren bütünsel bir öğrenmedir (PutzPlecko, 2008).

Bu araştırmadaki öğretmenlerin çoğunluğu MEB Okul Öncesi Eğitim Programı'nın kültürel miras eğitimine yönelik olarak beklentilerini karşıladığını ifade ederken, beklentilerinin karşılanmadığını ifade eden öğretmenler de bulunmaktadır. Beklentisinin karşılandığını ifade eden öğretmenler en çok programın esnek olma özelliğine, etkinlik türlerine, değerler eğitimi vurgusuna dikkat çekmişlerdir. MEB 3672 Aylık Çocuklar İçin Okul Öncesi Eğitim Programı'ndaki (2013), esneklik ilkesi ile programin çocuğun fiziksel çevrenin ve ailenin değişen özelliklerine göre uyarlanmaya ve bireyselleştirmeye uygun olduğu ifade edilmiştir. Ayrıca programda, kültürel ve evrensel değerlerin dikkate alındığı da belirtilmiştir (MEB, 2013). Öğretmenler, MEB Okul Öncesi Eğitim Programı'nın kültürel miras eğitimi açısından desteklenmesi açısından "kazanım-gösterge oluşturulmasına" ve "kavramların" oluşturulmasına dikkat çekmişlerdir. Araştırma kapsamında öğretmenlerin bazıları MEB Okul Öncesi Eğitim Programı'nı kültürel miras eğitimi ile ilgili kazanım ve 
göstergeler açısından yeterli bulurken bazıları yeterli bulmamıştır. Burada programın esneklik ilkesinden kaynaklı olarak öğretmenlerin ihtiyaç duydukları takdirde konularına, amaçlarına göre kazanım gösterge oluşturabileceklerini, programın buna imkân sağladığını vurgulamak gereklidir.

Öğretmenler, yaşadıkları şehir olan Denizli ile ilgili 17 kültürel miras öğesine programlarında yer verdiklerini ifade etmişlerdir. Bu noktada, öğretmenlerin Denizli ile ilgili kültürel miras unsurlarını mümkün olduğu kadar eğitim sürecine taşımaya yönelik bir çaba içinde oldukları söylenebilir. Kültürel mirasın okul öncesi eğitim alanında kullanılması çocukların sanatta yaratıcı düşüncelerinin gelişmesi için başlangıç noktası olabilir. Kültürel alanların duygusal ve sosyal yaklaşımı, çocukların sosyalleşmesine katkıda bulunduğu için çocukların zihinsel gelişimini de geliştirebilir (Christou, 1999; Bourotzoglou, 2018). Örnek olarak, müzeler ve arkeolojik alanlar sosyal ve eğitici bir rol üstlenmiştir. Küçük çocukların ilgi duydukları alanlarda katılımlarını sağlamak için düzenlenen etkinlikler onların kendilerini olayın bir parçası hissetmelerini sağlar (Gardner, 2006: 308). Araştırmacılar (Ramsey, 2006; Skjæveland, Moen ve Buaas, 2013) çocukların kimlik gelişiminin sağlanması ve kendi iç dünyasını tanıyabilmesi için, tarihi ve gelenekleri öğretmenin önemi üzerinde durmuştur.

Öğretmenlerin büyük bir çoğunluğu, kültürel miras eğitiminde materyal kullandığını ifade etmiştir. Bu bulgu, öğretmenlerin konu ile ilgili hassasiyetleri açısından değerlendirilebilir. Öğretmenler, kültürel miras eğitiminde kullandıkları materyallerle ilgili olarak ilk üç sırada yöresel eşyalar (kıyafetler, yiyecekler, çömlek, tahta kaşık, Buldan bezi vb.), görsel materyaller (fotoğraf, afiş vb.) videoları kullandıklarını ifade etmişlerdir. Öğretmenler kültürel mirasa yönelik kullandıkları materyallerin çeşitlilik gösterdiği ortaya konulmuştur. Öğretmenler malzemeleri temin ederken en sık kendi imkânlarına başvurmakta ardından ailelerden destek istemekte ve okulun imkânlarından yararlanmaktadırlar. Öğretmenlerin "tanıdıklarımdan temin ediyorum" cevapları ile birlikte kültürel miras eğitiminde materyal ihtiyaçlarını kendi imkân ve çabalarıyla temin ettikleri ve bu nedenle materyal konusunda desteğe ihtiyaçları olduğu söylenebilir. Okul öncesi eğitimde farklı türde çeşitli materyallerin kullanılması, çocukların ilgisini çekmek, etkinlikleri verimli hale getirmek ve kalıcı öğrenmeyi sağlamak açısından önem taşımaktadır (Öztürk Aynal, 2015).

Öğretmenlerin çoğunluğu kültürel miras eğitiminde sorunlarla karşılaştıklarını ifade etmişlerdir. Bu sorunlar arasında ilk sırada materyal yetersizliği gelirken maddi sorunların, okuldaki fiziksel şartların etkili olduğu ifade edilmiştir. Öğretmenlerin bazıları ailelerden, okul idaresinden destek göremediklerini belirtip, bazıları da kültürel miras eğitimi ile ilgili yeterli bilgi sahibi olmadıklarını ifade etmişlerdir. Bu bulgular, kültürel miras eğitimi kapsamında farklı açılardan eksiklikler olduğunu ortaya koymaktadir.

Öğretmenlerin büyük bir çoğunluğu, kültürel miras eğitiminde aile katılımı etkinliklerine yer verdiklerini belirtmişlerdir. Yapılan aile katılımı etkinlikleri içinde ilk üç sırada evlere etkinlik gönderilmesi, ailelerin sınıfa davet edilmesi ve evlere 
bilgilendirici dokümanların gönderilmesi gelmektedir. Sonuçlar, öğretmenlerin kültürel miras eğitiminde sıklıkla kullanılan aile katılımı etkinliklerine başvurduklarını göstermektedir. Skjæveland (2016), okul öncesi eğitim kurumlarındaki kültürel miras eğitimi çalışmalarının arttırılması ve aileleri de kapsaması gerektiğini ifade etmiştir.

Öğretmenlerin büyük bir çoğunluğu kültürel miras aktarımı ile ilgili herhangi bir projeye katılmadıklarını ve herhangi bir hizmet içi eğitim almadıklarını ifade etmişlerdir.

$\mathrm{Bu}$ araştırmanın sonuçları, okul öncesi eğitimi öğretmenlerinin temelde kültürel miras eğitimine yönelik hizmet içi eğitim almadığı, projelere katılmadığı, materyal konusunda sorunlar yaşadıklarını ifade etmeleri açısından önem taşımaktadır. Bazı sorulara verilen cevapların, konu ile doğrudan örtüşmemesi de öğretmenlerin konu ile ilgili bilgilendirilme ihtiyaçlarını ortaya koymaktadır. Bununla birlikte öğretmenler farklı materyaller kullanarak ve aile katılımı etkinlikleri ile kültürel miras eğitimini gerçekleştirmeye yönelik önemli çabalar sarf etmektedirler. Harrison, (2012) kültürel miras hakkında bilgi edinmeyi kimlik arayışı olarak görmektedir. Çocuk doğduğu toplumunun değerlerinin birçoğunu erken çocukluk evresinde yaşarken farkında olmadan öğrenir ve içselleştirir. Gerek tek gerekse çok kültürlü ortamda büyüyen çocukların anne-babalarının ve öğretmenlerinin kültürel miras eğitiminde içerisinde bir araya gelmeleri oldukça önemlidir. Çocukların, ailelerin ve öğretmenlerin gerek kendi kültürümüzün gerekse diğer kültürlerin varlığının birer zenginlik olduğunu anlamaları sağlanmalıdır. Kültürler geçmişteki yaşanmışlıklarla olgunlaşır ve zenginleşir. Her toplum farklı tarihsel süreçlerden geçer, farklı deneyimler yaşar ve bu nedenle de farklı kültürler oluşur. Farklı yaşanmışlıklar toplumlara farklı kültürleri miras olarak birakır.

$\mathrm{Bu}$ çalışmanın bulguları doğrultusunda, konu ile ilgili sonraki çalışmalarda hizmet içi eğitimler verilebilir, resmi ve özel kurumlar tarafından çeşitli kültürel miras eğitimi projeleri gerçekleştirilebilir, kültürel miras eğitimine yönelik materyaller arttırılabilir, yaygınlaştırılabilir. Ayrıca öğretmenlerin kültürel miras eğitimine yönelik algılarını, ihtiyaçlarını, bakış açılarını ortaya koyacak ölçme araçları geliştirilebilir. Öğretmenlerle kültürel miras eğitimlerinin detaylı bir şekilde incelendiği boylamsal çalışmalar ve bu eğitimin çocuklar üzerindeki etkilerine yönelik araştırmalar yapilabilir. 
Hakem Değerlendirmesi: Dış bağımsız.

Teşekkür: Katkılarından dolayı hakemlere teşekkür ederiz.

Destek Bilgisi: Herhangi bir kurum ve/veya kuruluştan destek alınmamıştır.

Çıkar Çatışması: Yazarlar arasında çıkar çatışması yoktur.

Etik Onayı: Bu çalışmanın tüm hazırlanma süreçlerinde etik kurallara riayet edildiğini yazar(lar) beyan eder. Aksi bir durumun tespiti halinde Güncel Turizm Araştırmaları Dergisi'nin hiçbir sorumluluğu olmayıp, tüm sorumluluk makale yazar(lar)ına aittir.
Bilgilendirilmiş Onam Formu: Tüm taraflar kendi rızaları ile çalışmaya dâhil olmuşlardır.

Etik Kurul Onayı: Pamukkale Üniversitesi, sosyal ve beşeri bilimleri bilimsel araştırma ve yayın etiği kurul karar tarihi 10/12/2020 ve karar sayıs1 93803232-622.02 ile uygun bulunmuştur.

Araştırmacıların Katkı Oranı: 1. yazar katkı oranı: \%34; 2. yazar katkı oranı: \%33; 3. yazar katk1 oranı: \%33.

Veri Kullanılabilirlik Beyanı: Araştırma verileri paylaşılmamıştır.

\section{KAYNAKÇA}

ACESE, (2009). Arts and Cultural Education at School in Europe, European Commission, Te Education, Audiovisual and Culture Executive Agency (EACEA P9 Eurydice), http://eacea.ec.europa.eu/education/eurydice/documents/thematic reports/113EN.pdf

Aerila, J. A., Rönkkö, M. L. ve Grönman, S. (2016). Field trip to a historic house museum with preschoolers: Stories and crafts as tools for cultural heritage education. Visitor Studies, 19(2), 144-155.

Aerila, J.-A. ve Rönkkö, M.-L. (2015). Enjoy and interpret picturebooks in a child-centred way. Reading Teacher, 68, 349-356. doi:10.1002/trtr.1313

Aslan, Z. ve Ardemagni, M. (2006). Introducing young people to the protection of heritage sites and historic cities. Rome, Italy: United Nations Educational, Scientific and Cultural Organization (UNESCO), Study of the Preservation and Restoration of Cultural Property (ICCROM).

Asunakutlu, T. ve Safran, B. (2004). Kültürel farklılıklardan kaynaklanan çatışmalara yönelik bir araştırma (Marmaris turizm sektörü örneği). Dokuz Eylül Üniversitesi Sosyal Bilimler Enstitüsü Dergisi, 6(1), 26-49.

Avcı, M., ve Memişoğlu, H. (2016). Kültürel Miras Eğitimine İlişkin Sosyal Bilgiler Öğretmenlerin Görüşleri. Elementary Education Online, 15(1), 104-124.

Badran, A. (2011). The excluded past in Jordanian formal primary education: The introduction of archaeology. In K. Okamura, ve A. Matsuda (Eds.), New perspectives in global public archaeology (pp. 197-215). New York, NY: Springer.

Barghi, R., Zakaria, Z., Hamzah, A. ve Hashim, N. H. (2017). Heritage education in the primary school standard curriculum of Malaysia. Teaching and Teacher Education, 61, 124-131.

Bickford, J. E. (2013). Examining historical (mis)representations of Christopher Columbus within children's literature (Paper 9). Retrieved from http://thekeep.eiu.edu/eemedu_fac/9 
Bourotzoglou, E. A. (2018). Art, cultural heritage and parent counselling activities, as pioneering practices for kindergarten class management. Journal of Contemporary Education Theory \& Research, 2(1), 21-26.

Campbell, R. (2001). Read-alouds with young children. Newark, NJ: International Reading Association.

Christou, E. ve Sigala, M. (2002). Innovation in hospitality and tourism education. International Journal of Tourism Research, 4(1), 65-67.

Cohen, B. (2011). Razumjeti sebe i druge: važnost mjesta odrastanja i vlastitog identiteta u multikulturalnom društvu. Dijete, vrtić, obitelj: Časopis za odgoj i naobrazbu predškolske djece namijenjen stručnjacima i roditeljima, 17(65), 2-5. from: Ivon, H. ve Kuscevic, D. (2013). School and the cultural-heritage environment: pedagogical, creative and artistic aspects. CEPS journal, 3(2), 29-50.

Collins, F. Ve Hollinshead, L. (2000). English and the historic environment: A teacher's guide. Education on site. London, England: English Heritage

Copeland, T. (1991). A teacher's guide to maths and the historic environment. London, England: English Heritage.

Copeland, T. (1993). A teacher's guide to geography and the historic environment. London, England: English Heritage.

Copeland, T. (2004). Heritage and education: A European perspective (pp. 18e22). The Hague Forum 2004.

Copeland, T. (2006). European democratic citizenship, heritage education and identity. Strasbourg, France: Council of Europe

Curtis, R. ve Seymour, C. (2004). Louisiana heritage education program and heritage in the classroom: Children's attitudes toward cultural heritage. Journal of Social Studies Research, 28(2), $20 \mathrm{e} 24$.

Dönmez, C. ve Yeşilbursa, C. C. (2014). Kültürel miras eğitiminin öğrencilerin somut kültürel mirasa yönelik tutumlarına etkisi. Elementary Education Online, 13(2).

Eryazıcıoğlu, E. ve Cengiz, H. (2018). İnsan Hakları Odaklı Bir Kültürel Miras Sistemi İçin Değerlendirme Modeli. Megaron, 13(4).

Fleer M. ve Robbins J. (2007). A cultural-historical analysis of early childhood education: how do teachers appropriate new cultural tools? European Early Childhood Education Research Journal, vol. 15, no. 1, pp. 103-119.

Gardner H. (2006). How the child perceives the world. Methods of teaching in harmony with the ways of thinking of the child. Athens: Atrapos.

Glover, A. (1996). Children and bias. In B. Creaser \& E. Dau (Eds.). The Anti-Bias Approach in Early Childhood. Sydney: Harper Educational.

Haddad, N. A. (2014). Heritage multimedia and children edutainment: assessment and recommendations. Advances in Multimedia.

Hade, D. (2013). Books in the classroom: The differences among us. Horn Book Magazine, 69, 642-645.

Harrison, R. (2012). Heritage: critical approaches. London: Routledge. 
Hewison, R. (1987). The Heritage Industry:Britain in a climate of decline.London: Methuen.

Hunter, K. (1988). Heritage education in the social studies. Bloomington, IN: Information Analysis.

Hunter, K. (1992). Heritage education: What's going on out there?. In Paper presented at the 107th annual meeting of the American Historical Association. Washington, DC: American Historical Association.

Ivon, H. ve Kuscevic, D. (2013). School and the cultural-heritage environment: pedagogical, creative and artistic aspects. CEPS journal, 3(2), 29-50.

Kailash, K. M. (2001). Curriculum Development for Cultural Heritage Studies, http://ignca.nic.in/n1001703.htm

Keskin, S. C. ve Keskin, Y. (2009). Cumhuriyet Dönemi İlkokul (İlköğretim 1. Kademe) Sosyal Bilgiler ve Onun Kapsamına Giren Ders Programlarında Bir Değer Olarak" Barış" in Yeri. Değerler Eğitimi Dergisi, 7(17), 69-92.

Kourmousi, N. ve Koutras, B. (2011). Steps for Life: “ Program of individual and social skills for kindergarten. Athens: Papazisis.

Köroğlu, Ö., Ulusoy Y. H. ve Avcıkurt, C. (2018). Kültürel Miras Kavramına İlişkin Algıların Metafor Analizi Yoluyla İncelenmesi, Turizm Akademik Dergisi, 5 (1), 98-113.

KTB (2020), Kültür ve Turizm Bakanlığı, Somut Olmayan Kültürel Mirasın Korunması Sözleşmesi Hakkında, https://aregem.ktb.gov.tr/TR-50837/somut-olmayan-kulturelmirasin-korunmasi-sozlesmesi-hak-.html. Erişim 9 Aralık 2020.

Langer, J. A. (1995). Envisioning literature. Literary understanding and literary instruction. New York, NY: IRA, Teacher's College Press.

Lesourne, J. (1993). Obrazovanje \& društvo: izazovi 2000. godine. Educa.

Lockey, M. ve Walmsley, D. (1999). Art and the historic environment. London, England: English Heritage.

Lukens, R. J. (2007). A critical handbook of children's literature (8th ed.). Boston, MA: Pearson.

Lusted, K. (2012). Does Early Years Education have a Role in Creating Children's Notion of Difference and Diversity? International Journal of Historical Learning, Teaching and Research, 11.1 (November 2012), 149-156.

Lynch, E. ve Hanson, M. (Eds.) (1998). Developing cross-cultural competence: A guide for working with children and their families (2nd ed.). Baltimore: Paul H. Brookes.

McKercher, B. ve Du Cros, H. (2002). Cultural tourism: The partnership between tourism and cultural heritage management. Routledge.

MEB, (2013). 36-72 Aylık Çocuklar İçin Okul Öncesi Eğitim Programı. Ankara.

Mutlu Öztürk, H. ve Öztürk, H. K. (2019). Hidrolik Santrallerin Turizm ve Kültürel Mirası Üzerine Etkisi. Journal of Tourism and Gastronomy Studies, 7 (3), 2321-2335. DOI:10.21325/jotags.2019.474. 
Nanzhao, Z. (1998). Suodnošenje obrazovanja i kulture u svrhu gospodarskog i ljudskog razvitka: iz azijske perspektive. In J. Delors, Učenje - Blago u nama (pp. 269-281). Zagreb: Educa. From: Ivon, H. ve Kuscevic, D. (2013). School and the cultural-heritage environment: pedagogical, creative and artistic aspects. CEPS journal, 3(2), 29-50.

Ogbu, J. G. ve Spajić, V. (1989). Pedagoška antropologija. Školske novine.

Öztürk Aynal, Ş. (2015). Eğitici oyuncak ve materyal hazırlamaya başlarken. Okul Öncesi Eğitimde Materyal Tasarlama. (Ed. Ş. Öztürk Aynal). (ss. 1-8). Ankara: Eğiten Kitap.

Özünel Ölçer, E. (2017). “İnsanlar, Gezegen Ve Refah İçin Bir Eylem Planı”: Somut Olmayan Kültürel Miras Ve 2030 Sürdürülebilir Kalkınma Hedeflerine Eleştirel Yaklaşım. Milli Folklor Dergisi, 15(116), 18-32.

Palmer, G. (1990). Preschool children and race: an Australian study. Australian Journal of Early Childhood, 15(2), 3-8.

Patrick, J. (1988). Historic preservation and the school curriculum. Speeches/Meeting Papers, Bloomington, IN

Pownall, J. ve Hutson, N. (1992). A teacher's guide to science and the historic environment. London, England: English Heritage

Putz-Plecko, B. (2008). The promotion of cultural knowledge, creativity and intercultural understanding through education. Brussels, Belgium: Parliamentary Assembly, Council of Europe.

Ramsey, P. ve Myers, L. (1990). Salience of race in young children's cognitive, affective and behavioral responses to social environments, Journal of Applied Behavioral Psychology, 11, 49-67

Ramsey, P. G. (2006). Early childhood multicultural education In B. Spodek ve O. N. Saracho (eds.), Handbook of research on the education of young children (pp. XVI, $600 \mathrm{s.:} \mathrm{fg.).}$ Mahwah, N.J.: Lawrence Erlbaum.

Richards, G. (2001). Cultural Attractions and European Tourism. Wallingford: CABI.

Richards, G. (2003). What is cultural tourism. Erfgoed voor Toerisme. Nationaal Contact Monumenten.

Ridgway, A. (2014). The past-present dialectic: A new methodological tool for seeing the historical dynamic in cultural-historical research. In Visual methodologies and digital tools for researching with young children (pp. 55-72). Springer, Cham.

Riihelä, M. (2001). The Storycrafting Method \& The Storycrafting Video.Helsinki, Finland: Stakes. From Aerila, J. A., Rönkkö, M. L. ve Grönman, S. (2016). Field trip to a historic house museum with preschoolers: Stories and crafts as tools for cultural heritage education. Visitor Studies, 19(2), 144-155.

Schindler, R. K. ve Bonebright, T. L. (2011). Teaching archaeological ethics: Student attitudes towards cultural heritage. Retrieved from http://www.depauw.edu/files/resources/teaching-arch-ethics.

Serafni, F. (2014). Reading the visual: An introduction to teaching multimodal literacy. New York, NY: Teachers College Press. 
Skjæveland, Y. (2016). Teaching Cultural Heritage In Culturally Diverse Early Childhood Centres In Norway. History Education Research Journal, 13(2), 82-92.

Skjæveland, Y., Moen, K. H. ve Buaas, E. H. (2013). Danning gjennom historie og tradisjonsformidling i barnehagen. In I. Pareliussen (ed.), Proceedings of FoU i praksis 2012 (pp. 9 s). Trondheim: Akademika.

Smardz, K. ve Smith, S. J. (2000). The Archaeology Education Handbook: Sharing the Past with Kids. AltaMira Press, A Division of Rowman \& Littlefield, Publishers, Inc., 1630 North Main Street, Suite 367, Walnut Creek, CA 94596; Web site:(http://www. altamirapress. com).

Stevanović, M. (2002). Modelski pristup baštini kao izvorištu odgojno - obrazovnog rada s djecom predškolske i mlađe školske dobi. In R. Bacalja, Živa baština (pp.145-155). Zadar: Visoka učiteljska škola u Zadru.

Stone, P. G. ve Molyneaux, B. (1994): The Presented Past: Heritage, Museums, and Education, London: Routledge.

Terhart, E. (2001). Metode poučavanja i učenja; Uvod u probleme metodičke organizacije poučavanja iučenja. Zagreb: Educa

Uçar, M. (2014). İlköğretim düzeyinde kültür varlığı ve koruma konularındaki eğitiminin etkinliği ve sivil toplum örgütlerinin eğitime katkısının değerlendirilmesi. Megaron, 9(2), 85.

Virta, A. (2015). Historiaa Koiramäen kautta: Miten lapset tulkitsevat mennyttä kuvakirjasta. [History through the picture book of the Doghill Farm by Mauri Kunnas: How children interpret the past from the picture book]. Kasvatus \& Aika, 4, 25-39.

Vygotsky, L. S. (1997). The history of the development of higher mental functions. In R. W. Rieber (Ed.), The collected works of L. S. Vygotsky (Vol. 4). New York: Plenum Press.

Yeşilbursa, C. ve Uslu, S. (2014). The comparison of Turkish and American preservice social studies teachers' attitudes toward heritage education. Turkish Studies, 9(8), 879-891. Retrieved from http://www.turkishstudies.net/ Makaleler/1741598746_51Ye\%C5\%9FilbursaCemilCahit-vd-sos_S-879-891.pdf.

Yıldırım, A., ve Şimşek, H. (2016). Sosyal bilimlerde nitel araştırma yöntemleri. Ankara: Seçkin Yayınları.

Youngs, S. (2010). Peritextual discussions of historical fction picturebooks. In R. T. Jiminez, V. J. Risko, D. Wells Rowe, \& M. K. Hundley (Eds.), National reading conference yearbook (Vol. 59, pp. 16-22). Oak Creek, WI: National Reading Conference.

Youngs, S. (2012). Understanding history through the visual images in historical fction. Language Arts, 89, 379-395.

Youngs, S. ve Serafni, F. (2011). Comprehension strategies for reading historical fction picturebooks. The Reading Teacher, 66(2), 115-124.

Zeppel, H. ve Hall, C. M. (1991). Selling art and history: Cultural heritage and tourism. Journal of Tourism Studies, 2(1), 29-45. 